\title{
Children With Parent-Child and Peer Relationship Problems Sandplay Therapy Case Study
}

\author{
Park, YounSoo*
}

\begin{abstract}
$<$ Abstract $>$
The child in this case was not separated from the mother due to unstable attachment, which delayed the ego-development of autonomous and independent school age. The mother child was unable to express his or her feelings and intentions voluntarily and had a strong tendency to depend on the mother, which limited the experience of positive communication with others. It aims to heal the experience of attachment trauma and promote ego-development and growth of delayed children through sandplay.17 sessions were conducted over 6 months, and a total of 17 sand photos are included in this case. In the process of improving self-relationships along with ego-development while playing sand, children have improved their ability to form intimate relationships through social development. The way a child expresses his or her intentions to a friend in a language is that the child overcomes the problem of damaged attachment and emotional control of Mowa through the sandplay. He showed the appearance of entering into a peer relationship through the separation of Mowa. Through the experience of the relationship with the therapist who endures and contains the child, the child is able to resolve and adapt to the conflict in the social environment while maintaining a stable emotion. As a result, children showed positive changes in their ability to accept themselves and others, develop emotional regulation, and improve school adaptation.
\end{abstract}

Keyword : Early Relationship, Sandplay therapy, ego development, attachment

\footnotetext{
* Doctoral candidate, Department of Child Welfare, Namseoul University (youn4992@hanmail.net)
} 
Journal of Symbols \& Sandplay Therapy, Vol.11 No.2.

\section{INTRODUCTION}

As children in lower grades of elementary school expand their social network from home to school, they are required to make various social adjustments (Elkind, 2000). Children at this stage of life are in the process of physical and psychological development through which they ought to perform various development tasks, such as forming and growing their ego and engaging in peer relationships (Kang, 2008; Kim, 2009). Once children enter upper elementary grades and go through adolescence, they become strongly independent and attempt to break free from parental control. Peers become the center of their social relationship as they spend more than half of their daily activities with them. Peer relationships not only enable children to acquire social and interpersonal skills and to form their ego identity, values, beliefs but also influence their sense of gender role, morality, and self-concept (Furman, 1982). Because peer relationships have greater impact on children as they move up grades in elementary school, it is highly important to understand how children perceive peer relationships and to explore factors that affect peer relationships.

A peer group is a social group of people who have similar age, gender, school grades as well as psychological and physical development and are socially identified as being the same (Lee, 2001). According to Rubin, children in their early stage of life greatly depend on their parents both physically and psychologically and learn from the parent-child relationship. As they grow, however, they develop their own capacity and independence. And as they interact within a more fluid, wide-ranging environment, peers become increasingly important (Yoo, 2005). Many adolescents wish to be part of a small group or a peer group. A peer group gives its members a unique sense of security and support, thereby bringing comfort to their uncertain ego-consciousness. Moreover, social interactions within a peer group allow its members to develop a code of conduct and values (Lee, 1994). Children feel a direct sense of satisfaction by socializing with their peers and express their own conflict or inferiority through their peers. When they learn that other children have the same problems as their own, they feel at ease and experience a reduced sense of guilt. Getting along well with peers could help develop inner maturity, social adaptability, and vitality (Kim, 2000). Azmitia explained that peer relationships 
play an important role in child development (Lee, 2007). First, children discover their own sense of identity in a larger social network of peers. Second, children develop the basics of social cognitive skills, including the ability to understand the interests of others and to communicate with others, through peer relationships. Third, children gain recognition from others by acquiring physical, cognitive skills from peer relationships. Fourth, peer interaction provides emotional support in unfamiliar or threatening situations in which parents cannot provide help. Peer relationships therefore play an important function in childhood development.

A factor that affects children's peer relationships is the attachment relationship with their parents. Attachment is a strong, intimate emotional relationship between children and their caregivers. The quality of attachment varies according to the caregiver's sensitive parenting behavior (Bowlby, 1969). The formation of children's personality is most influenced by their attachment with the parents. Indifference, neglect, difficulty in exercising control, or apathy on the part of the parents lead to the child's maladjustment. This means that when there is an unstable parent-child attachment, the child experiences a low level of self-satisfaction (Collins \& Read, 1990), faces problems in communication, and may not be able to satisfactorily resolve conflicts in interpersonal relationships. (Cheon, 2003).

Experience of repeated interaction with the mother shapes children's attachment style during adulthood as well as the formation of attachment with their own chidlren. Attachment theorists call this "attachment continuity," which is the cause of a secure or insecure mother-child attachment (Jang, 1997; Feeney, 1995). Compared to securely attached mother and child, those who are insecurely attached lack empathy (Barrett, 1987; Eisenberg, 1989), pay minimal attention to the other or demand excessive attention and contact from the other (Kim, 2008; Yoon, 2011), and experience difficulty in mother-child communication as negative emotions are expressed both verbally and nonverbally (Kim, 2008; Oh, 2010). While many factors influence the mother-child communication, such as parenting attitude, family structure, socio-economic background, and the child's age and temperament, attachment is not only the cause but also the effect mother-child communication. Parenting attitude greatly impacts the mother-child relationship and the child's communication with peers, and an insecure attachment can inhibit the child's ego-development. 
Journal of Symbols \& Sandplay Therapy, Vol.11 No.2.

For children, ego-development is of paramount importance. The birth of the ego-the center of consciousness and its master-is the germination that leads to the creation of the world. It is also the beginning of the discovery of one's identity as an individual. Achieving creation, ego growth, and integration are important tasks for children. Individuals do not go through a uniform development process. Rather, by achieving their unique individuation, they develop a positive self-esteem and live life as who they are with a valuable self-perception. The growth and development of the ego, which take place during childhood, plays an integral part in the development of self-esteem, a positive self-view, and sociability. How children perceive themselves affects their attitude toward others: whether it be more positive or negative. In other words, self-esteem affects children's relationships with others, which includes peers. Cooper Smith (1967) saw self-esteem as the recognition of one's self-worth and positive self-assessment and explained it is deeply associated with interpersonal relationships and social adaptation. As a suggestion of one's personal judgement of his own worthiness, self-esteem is expressed as either positive or negative attitude. It indicates the extent to which the individual believes he is capable, significant, successful, and worthy. Children with high self-esteem-i.e., those who recognize and trust their worth-behave positively, are responsible, tolerate frustrations, and are proud and satisfied of their actions (Winggins \& Winggins, 1992). On the other hand, children with low self-esteem are unable to express their emotions properly and thus face difficulties in interpersonal relationships. They also have trouble adapting to school life, and their poor social skills make it challenging to interact with others (Cha, 2005). When we fail to establish a positive view of the ego, we are unable to experience self-worth and success and also fail to recognize the worth of others, which may result in antisocial behaviors (Ahn, 2008).

There are a range of treatment methods to resolve children's psychological conflict and problem behavior: sandplay therapy, art therapy, play therapy, and other therapeutic techniques using different medium. Among them, sandplay therapy makes use of sand and water (which are natural objects) and also items found in our daily lives (which allows three-dimensional expression). These items, or figures, are freely arranged inside the sand tray to express the images of the unconscious. As it is difficult for children to express their thoughts and emotions verbally, they find it challenging to describe their inner problems and become conscious of them 
through verbal means. In that regard, sandplay therapy is well suited for working with young children as it enables them to manifest their unconscious images in a natural way through familiar items and play. Also, the free and protected space provided by sandplay therapy enables children to feel relaxed and freely express their unconscious images, which supports regression and activates self-healing energy so as to help children achieve their individuation process.

Sandplay therapy was developed by Dora Kalff, who applied Carl Jung's analytical psychology to Margaret Lowenfeld's World Technique. Kalff believed that sandplay therapy facilitates the individuation process by helping clients face their unconscious, activate their innate healing energy, and go through a normal ego-development process. Facing the unconscious, which is part of the individuation process, occurs naturally through the play of working with sand and water and arranging figures. The sandplay therpay room protects clients from the outer world both emotionally and physically. It is also the space in which clients receive empathy and are safeguarded against their negative inner aspects (Jang, 2017). The hands, which touch the sand, connect the psyche and the body (Ammann, 2001). In sandplay therapy, figures are children's words and play is their language. (Landreth, 2002).

Sandplay is a nonverbal therapeutic technique, which means that thoughts that cannot be expressed verbally can be manifested as images through sand tray and figures and at the same time become conscious (Chae, 2000). It is effective for children, who generally have poor language skills. Sandplay encompasses both the archetypal world and the personal inner world and is a tool that allows children to come in touch with their everyday outer reality. There is the assumption that symbolic play facilitates communication between consciousness and unconsciousness (Boik \& Goodwin, 2000). The basic premise of sandplay therapy is that the human psyche has an innate healing energy (Jang, 2017).

Jung said that the individualization process is the history of psychological development of an individual and that it falls into two parts (Neumann, 2004). The first half, or the childhood, is a period of physical and cognitive development as well as ego development through which chidren becomes less reliant on their parents and increasingly independent (Jung, 2006g). During this process of ego independence, parent-child conflict begins. Plus, 도덕성 develops within the ego, coupled with the separation of the ego and the shadows. The latter brings about conflicts, 
Journal of Symbols \& Sandplay Therapy, Vol.11 No.2.

which lead to the manifestation of problem behaviors (Jung, 2006h). Through the conflicts, the ego interacts with the Self and develops. However, experiences of trauma such as separation from mother, loss, neglect and abuse as well as knowledge-oriented modern education are coercively unilateral and focus on the goal only. Consequentially, the child's ego becomes distant from the Self (Jung, 2006b) and brings about an imbalance between consciousness and unconsciousness, which hinders ego development and manifests in the form of problem behavior.

The child introduced in this paper did not achieve separation from her mother due to insecure attachment, and thus her ego development was delayed. She did not develop the level autonomy or independence appropriate for children at her age. She was unable to express her own emotions and opinions and largely depended on her mother, which limited the experience of positive communication with others. The goal of this client's sandplay therapy was to bring healing to her attachment trauma experience and facilitate her delayed ego development and growth.

\section{П. CASE OVERVIEW}

\section{A. Client's Behaviors and Reasons for Therapy}

The client was in her fifth year in elementary school when she came for therapy. Her physique was that of her peers, though a bit skinnier. She could not look at the therapist in the eye during their first meeting, perhaps out of shyness. When the mother told the client to say hello, she nodded her head without a word. The therapist had the impression that the client lacked confidence and found it difficult to be in an unfamiliar setting and in front of an unfamiliar person. The mother expressed her concern that the client seemed unable to express her opinions to her peers at school and get along with them. Despite being in the upper grades, she had a hard time going to school alone that the mother had to accompany her. While she experienced difficulties in expressing herself in the outer world, the client often engaged in a conflict with the mother: She would disobey the mother's commands and talk back. The client lacked social skills and could not perform basic daily routines on her own, 
which forced the mother to be involved in all aspects of her life. The mother further explained that the client lacks the ability to express her emotions and opinions to not only her peers and schoolteacher but also to the mother, and that she handles her emotions through irritation and crying. She therefore experiences trouble with her peers and also with the mother. The client said after moving up to upper grades in school, she found it difficult to keep up with the school curriculum, especially mathematics. She also reported having a hard time going to school alone without the mother and getting along with peers who have strong personalities. The mother brought her child to therapy to resolve all the problems mentioned above.

\section{B. Client's Development History and Family History}

During pregnancy, the mother experienced both physical and psychological distress as she had to take care of her sick mother-in-law. The client started walking at 14 months of age and was slow in terms of language, self-help skills, and physical development. At around the age of one, she had been hospitalized for about two weeks due to injury. She cried a lot, became easily scared, was reluctant to approach or be held by other people, and always clung to her mother. She did not eat unless the mother fed her until the age of three and was a rather particular about her food. Compared to other children of her age, she was also late in being able to dress herself and the mother had to do it for her. She was sent to the day care at the age of three, as the mother was busy taking care of her younger sister. The sisters are two years apart. The client easily adapted to the life at day care but after staying at her aunt's place for three days when the mother was sick, she refused to go to the day care. At this time, the client communicated her needs to the mother through simple language but did not communicate with anyone else. She entered kindergarten at the age of six. It was reported that she was unable to clean up after herself and carry out tasks that children in her age usually were capable of. She also did not get along well with her peers due to communication trouble. While she was still introverted at the time of therapy, she frequently talked back to her mother and did not follow her directions. She often fought with her younger sister and became angry with her. At home, she was aggressive and irritable. Outside of home, however, she could not express her opinions and intentions. And because she was slow in terms of language 
Journal of Symbols \& Sandplay Therapy, Vol.11 No.2.

comprehension, she was rather incapable of understanding other people's situations and needs. At school, she did not get along with peers who are strongly assertive and therefore avoided them. She also showed great discomfort and shyness around adults outside of the family. In short, she experienced great interpersonal difficulties.

The client's mother is the youngest of four children. Her parents had separated when she was young. Her three siblings lived with their mother; she was the only one living with her father. Because the family was not financially well off, she had to get a job at a young age. She married her first husband at the age of 24 but divorced him as he was abusive and had an affair. There were no children between them. Then her acquaintance introduced her to another man, with whom she got remarried. However, even her second marriage life was not so satisfying. She anticipated having her first child, the client, but admitted that she was not able to provide stable care due to the conflict with her husband as well as financial hardships. While the mother complained that the client depended too much on her, she intervened and nagged the child out of anxiety. She also wanted the client to excel at school and therefore invested a lot in private education. But the client had a hard time keeping up with the studies and that appeared to have lowered her confidence level. In contrast, the younger sister was rather smart and thus the parents had high expectations for her. Though the younger sister helped out the client a lot, they often fought.

The client's father is the youngest of six children. He is not so close to his siblings. He runs a small business on his own. He is overly sensitive about money and cares much about how other people think about him. According to the mother, he is patriarchal and would communicate what he had judged from an objective point of view to the child instead of engaging in a warm, emotional relationship.

\section{Therapeutic Approach}

It seemed that the mother had a desire to achieve what she was not able to through the child, such as learning, and therefore spent on private education despite the family's financial circumstances. As she was separated from her mother and other siblings and lived with her father, she probably lacked the experience of motherly warmth. So as a compensation to the 
lack of emotional care during her childhood, the mother wanted to be a good mother. But instead her ambition led her to overly control the child and develop excessive expectations that she had to study things that are too difficult for her academic level. As a result, the client's autonomy and independence were disrupted. The client did not experience emotional acceptance during infancy, a period in which emotional care is necessary. Therefore she lacked confidence, expressed her opinions through irritation and crying, and experienced difficulties in getting along with her peers.

Erich Neumann explained that difficulties in the development process due to a disruption in the primal relationship is attributable to the failure of the personal mother and the resulting manifestation of the negative mother archetypal energy (Jang, 2017). In this case, therapy must provide an environment in which the primal relationship can be reconstituted and the damaged ego-Self axis be reproduced.

Sandplay therapy was administered to resolve the development of such needy or fixated ego. Kalff (1980; 2003) explained that through sandplay theray, the ego that is fixated due to neediness can reconstitute a new psychology and go through a process of normal ego development. In other words, sandplay therapy can help children who have failed to achieve normal ego development for the creation of a health ego. Through the process of discovering her genuine self, the client can not only improve her social relationships (with family, peers and others) but also express her emotions and opinions in an appropriate manner in lieu of becoming irritable or silent. The client's introverted and withdrawn attitude in the outer reality is deeply associated with the mother's childrearing attitude as well as the family environment. Restoring the trust relationship between the mother and the child and giving back the experience of secure attachment helps restore the delayed ego development, which would allow positive self-expression and positive peer relationships for the client.

\section{SANDPLAY THERAPY PROCESS}

The client received 17 sessions of individual sandplay therapy from April to September of 
Journal of Symbols \& Sandplay Therapy, Vol.11 No.2.

2019. She created a sand picture in every session. The therapy was terminated at the request of the mother, who expressed her wish to end therapy at session 15 due to financial reasons as well as the fact that the client has shown improvements in peer relations and self-expression. The client was told in advance that she would no longer come for therpy after two more sessions, and her process ended at session 17. This paper therefore contains 17 sand pictures.

In the early part of her sandplay therapy, the child expressed the chaos and confusion of her ego through the play of mixing sand with water. She used a lot of water. Then in the middle part of her process, she expressed her inner conflict-which was experienced through the encounter with her unconscious - through various struggles and incidents that resulted in deaths. She mashed and mixed the sand, and used animal and food figures. The late part of the process showed the construction of the ego and the Self and adaptation to the collective. One of her sand pictures depicted a rural village of animals in which the bear family and their friends were farming and a duck was making rice cakes as there was nothing to eat. Farming and making food are an expression of nurturing and the rebirth of a new ego. Kalff (1989) created what is known as "sandplay" today based on Jungian psychology, oriental philosophies and Lowenfeld's technique. The different stages of Kalffian sandplay therapy was influenced by the psychological development process identified by Neumann (1973). Neumann's development theory is composed of five states: the chaos stage, the animal-vegetative stage, the fighting stage, the ego-Self axis stage, and the adaptation to the collective stage (Turner, 2014). In contrast, Kalffs development theory is comprised of three phases, which are the following:

First is the chaos and the animal-vegetative phase. This stage reflects the child's emotional chaos and confusion and usually shows up in the first sand picture or the early sand pictures. Usually, children's sand pictures appear in a state of chaos rather than having a certain theme and are characterized by an overcrowded sand tray with no certain patterns with mostly animal and vegetable figures (Turner, 2014). This stage may display a very complex or desolate, dry, lifeless scenes that reveal all aspects of the psyche at once. In addition, there may be a jungle, dinosaurs and many representations of water as an expression of the activation of the unconscious instinct, which remains suppressed by ethics, norms, and rules. Neumann (1973) said the chaos reveals the early state of the ego that remains undifferentiated and confused, and that 
it is comparable to the early mother-child unity in which the newborn is not aware that he or she and the mother are two different beings. The appearance of animals and vegetables can be comparable to when children begin to separate from their mother in terms of development. This is also called the "rapprochement stage," which is when object constancy develops. At this time, the type of animals chosen by children has a significant meaning. Depending on the developmental stage they arein, the animals can be primitive or more domesticated. Generally, choosing a dinosaur instead of a horse or a cow represents greater aggressiveness on the part of the child (Lee • Go, 2002).

Second is the fighting phase. After the chaotic animal-vegetative stage, opposites appear and engage in fights. Many war scenes or other destructive scenes can be observed in this stage. Examples are fights between enemies and allies; different-colored dinosaurs; the left side and the right side, as marked by a diagonal line in the sand; figures from animations or predatory animals trying to hunt weak animals, etc. (Kim, 2005). In this phase the ground often explodes or someone or something gets shot by guns. Towards the middle part of the therapy, the fights become more intense and organized; the resulting destruction no longer take on a disorganized form but are more balanced. Also, a hero would appear and display his or her energy. At around this time, young girl clients would use figures to connect fantasy with their instinct. For example, they would imprison a figure with whom they identified themselves.

Third is the adaptation to the collective phase. After spending enough time in the fighting phase, the sand pictures would show scenes that imply integration towards the stage of adaptation. Children would become immersed in their inner world, integrate the things inside it, and then become adapted to the collective (Turner, 2014). The sand pictures would reflect normal, everyday life scenes and Neumann considered this as the phase in which children getting ready to be in a relationship with the outer world. It is also at this time when children show a world view geared towards outside such as going to school and engaging in relationships with their peers, away from the initial mother-child relationship. Order is restored, balance is formed between nature and human, and routine is established in everyday life. Animals live in an appropriate environment, villages and cities are in a balance, and scenes of Thanksgiving can also be seen. Villages through which people are connected to the community can usually be 
Journal of Symbols \& Sandplay Therapy, Vol.11 No.2.

seen in girls' sand trays. Towards the later part of this phase, young girls use highly feminine symbols.

The later pictures of sandplay therapy contain circles - symbol of totality and wholeness and squares. These shapes represent the integration of instinctual energies through sandplay (Kalff, 1989). The three developmental phases are the process of ego development and at the same time of improving the ego-Self relationship, the process of developing sociality, and the process of improving one's relationship with others including parents (Lee el, 2002). This paper relied on Kalffs developmental phases, taking into consideration of the fact that Kalffs approach is the most widely-adopted one in the world.

In case of the client, the chaos of the animal-vegetative phase was represented through the use of many water symbolisms and animals. Her fighting stage showed conflicts and struggles, wealth and poverty, and food. As for the adaptation to the collective phase, her sand picture showed, though represented by animals, a community in which the members are farming and making rice cake.

\section{A. Chaos and the Animal-Vegetative Phase}

\section{Session 1}

Contrary to the mother's report that the client hardly talks, she did express her emotions when the therapist waited. Though she is a bit timid, she was willing to express herself and communicate as long as she felt safe to do so. The empty space in the left half of the sand tray seems to emanate the feeling of frustration, loneliness, and isolation that the client would have felt when not being emotionally supported by the mother. A noticeable figure in the first sand picture is the bed. Considering that the bed is a symbol of rest-which is associated with sleep - and helplessness and unconsciousness, the client might have been extremely exhausted psychologically. Perhaps this was so because she felt that no one understood her. Perhaps the child became irritated and refused to talk out of the feeling that there is no use in talking to the mother. But it appeared that the client's unconscious knew that she cannot stay in that way forever, which is represented by the phone-symbol of communication-next to the bed (Ackroyd, 1993). And interestingly enough, there is a closet next to the phone. 
In the West, the closet symbolizes secret, though that is not the case in Korea. In the film Chronicles of Narnia, children enter into a world of unconsciousness through the closet. This particular closet in the client's sand picture reminds us of the closet in the film (https://namu.wiki/w/). In the film, the closet appears somewhat scary and therefore the children need courage to go through it at first. Perhaps, in order to overcome the state of helplessness and become healthy, be in a relationship with her peers and communicate her opinions clearly, the child needs to muster the courage to enter the dark, scary-looking closet. For her, the therapeutic process is probably linked to going into that closet to heal and to grow. What is also interesting is the mirror placed next to the closet. The mirror is a symbol of our self-reflection and identity. Through the objective reflection in the mirror, we experience and become aware that we are separate beings from others (Cooper, 1978). In front of the mirror is a rabbit, which is placed close to the client. The client explained that this is a place where the rabbit lives alone. There are two meanings to "living alone." It could mean that one is isolated psychological and socially and therefore in a state of extreme loneliness. Also, Koreans usually visualize a rabbit pounding rice in a mortar under a laurel tree on the moon according to an old folklore, an image which could represent that the child ought to attain and achieve something. Among Native Americans living in the eastern woodlands, the rabbit is known as the trickster (Cooper,1978). It appears that the child wants to satisfy her desire to regress by playing freely and mischievously like the rabbit. Placed in front of the rabbit's feet is a toy duck with a string attached to it. The duck is a symbol of the connection between the sky and earth and the mind and body. The string attached to the duck accentuates that connection. Perhaps the duck is indicating that because the child is feeling helpless as she is disconnected with a certain energy and therefore there is the need to reconnect with that energy. On the other hand, when thinking about rubber duck toys that children play with in the bathtub, the duck could represent regression to childhood. Perhaps the client is at a dilemma: She is torn between achieving growth and independence, as represented by the closet, and achieving regression, as represented by the duck. One other possible indication is regression; Rather than an independent being who is capable of clearly delivering her opinions, she is experiencing regression and therefore communicates through crying, whining and irritation. So maybe the 
Journal of Symbols \& Sandplay Therapy, Vol.11 No.2.

client is experiencing a conflict between regression and independence. In that regard, perhaps this particular sand picture represents the need for her to overcome her fear and break away from the regression. She needs to go inside the closet to embark on a journey to confront her fear. She seems to be in confusion between the state she is in now (regression) and the state that she ought to be in to find her genuine ego (independence).

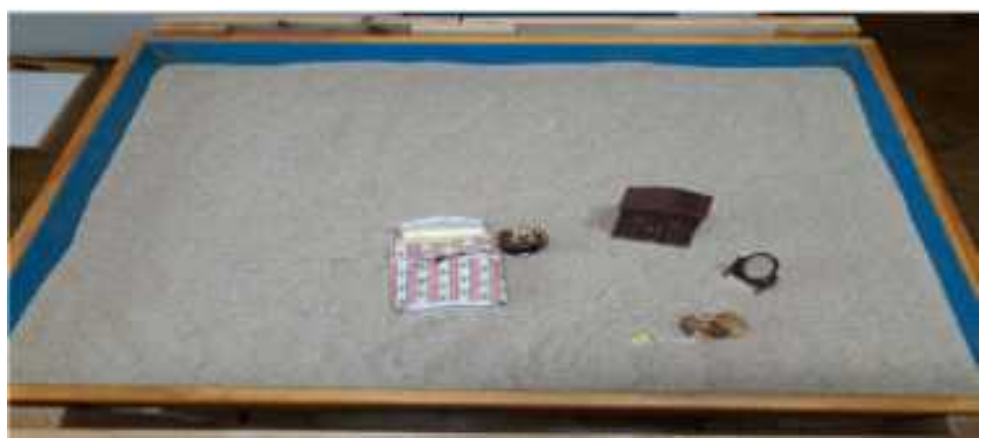

Sand picture \#1

\section{Session 2}

After browsing through the figure shelves, the cilent selected some figures and sat in front of the sand tray without a word. She first placed a bed in the tray, followed by a closet, a piano, a rabbit, and a badger. Then she placed a faucet figure to the left of the bed. Afterwards the played with sand by touching or spreading it out in both directions. "This is the squirrel's home. The squirrel's alone." She explained that the squirrel wants to live alone because it "hates it when mom nags." As she said this, she looked up and smiled at the therapist for the first time. The fact that the client took a long time choosing figures may indicate that she finds it difficult to make decisions on her own.

In Norse mythology, the Ratatoskr is a squirrel who lives on the world tree Yggdrail. Ratatoskr presaged rain, water and snow. The squirrel ran up and down Yggdrasil to carry distressful messages between the eagle perched atop Yggdrasil, and the venomous serpent Niðhöggr, who dwells beneath one of the three roots of the tree (Turner, 2014). As a symbol of resentment and evil, the squirrel ignited disputes between the eagle and the snake (Cooper, 1978). Realizing one's Self requires endless struggles, as seen from the squirrel that initiates 
fights between the eagle and the snake. Perhaps, through sandplay, the client became aware of the confusion between her inner unconscious and the way she relies on the mother in outer reality. This could symbolize the beginning of a conflict between the desire to live life the way who she is and to live as the child who was shaped by the mother.

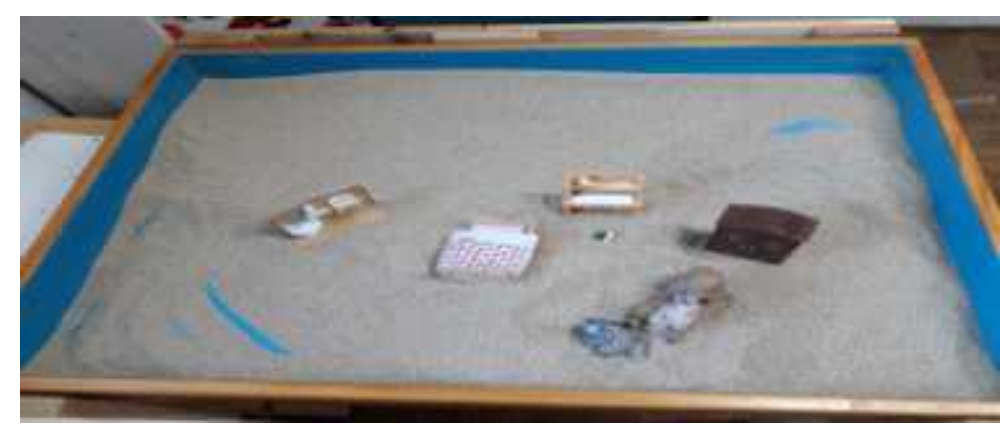

Sand picture \#2

\section{Session 3}

The client looked at the therapist and, in a very small voice, said, "Water." It was the first time she had verbally expressed her needs. In this session, she used water for the first time. She mixed water and sand and spent a long time exploring them without saying a word. Her behavior seemed to be associated with the act of descending deep down into the unconscious. As she continued to mix water and sand, she relocated the figures so that they would not become submersed in water. The client looked like the Creator constructing a new world. Water symbolizes an intangible state of chaos. Jung (2006h) said the collective unconscious is in a state of darkness and dawn. Inside, the subjects and the objects cannot be differentiated and are in a state of union as if they are one, i.e., in a state of chaos. Just like the collective unconscious, water is in a state of undifferentiation and symbolizes the potential of being in union with various materials. Eliade (1952) referred to water as "the source of all existence" and "the storage." Water contains the potential for life and growth but is yet in a state of chaos with no concrete form. It also symbolizes the unconscious (Cooper, 1978). It appears that through sandplay, the client is ready to descend into her unconscious and face her ego, which is in a chaotic, undifferentiated state. 


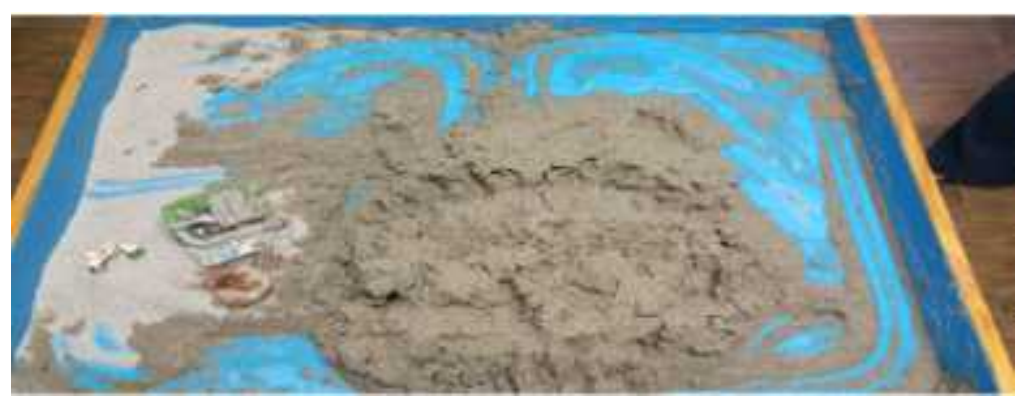

Sand picture \#3

\section{Session 4}

The client poured a lot of water inside the tray and mixed water with sand. She repeatedly collected and dispersed sand, dug a hole in it and poured water inside, and knead the mixture. She kept her head low while mixing sand and water. Then in the left rear corner, she placed a TV and a sofa, and a badger on the sofa. "I like it because there's no nagging mom." Then she pointed at the badger and said, "Bath, because [the badger] played in the mud." She also pointed at the house figure saying, "It's ruined." When the therapist asked how the client felt, she said, "Good. Rotten sea. [The racoon] died from hunger. The racoon got rotten so the sea got rotten."

In sandplay, water erodes the sand and makes it into mud, thereby blurring boundaries (Turner, 2005). Using wet sand is the ego intention to deal with emotional aspects (Ammann, 2001: Grubbs, 1995). Water can represent the ocean, symbol of the unconscious. Children who had been abused in particular use a lot of water to represent flood or play with completely-soaked sand (Grubbs, 1995; Mitchell, 2012). The rotten sea and the racoon that died from hunger seem to be an expression of the anger that the client felt while receiving negative emotions from her mother. The ruined house, the rotten water, and the dead racoon seem to symbolically represent the deaths in the client's unconscious. New birth comes after death. Just as the world of chaos died and a new world was created after a great flood (Genesis 7:17-24), we may be able to see things that are no longer needed in the client's inner world die and new things being created. 


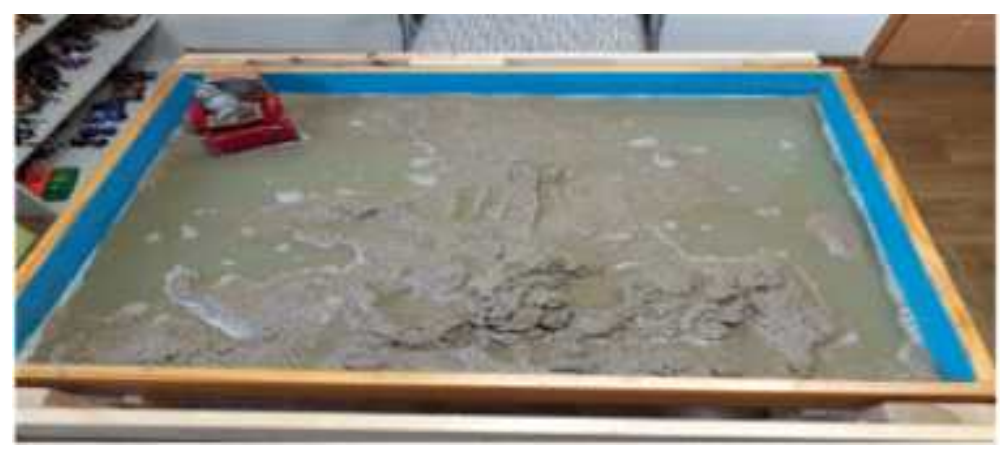

Sand picture \#4

\section{Session 5}

"They moved because the house got ruined. There's no mom and dad." After saying this, the client looked at the therapist and smiled slightly.

The client poured water into the sand tray several times. She was careless about pouring water in, which appeared gratifying. A significant amount of water represents flood, tsunami, death in the mire, etc. Psychologically, this indicates the suspension of all functions and a dismantlement of an entire world and also facilitates the meeting with its original source (박행 자, 2012). Flood in the early phase of a sandplay process represents a state of chaos in which all energies remain stagnant. It is a sign of a severe trauma in case of children who experienced trauma in early years of life. Flood that appears in the middle phase of a sandplay process represents the meeting with the unconscious and serves as a prelude to a rebirth after death (Turner, 2005). Flood can also symbolize the eruption of inner emotions. There is the process of

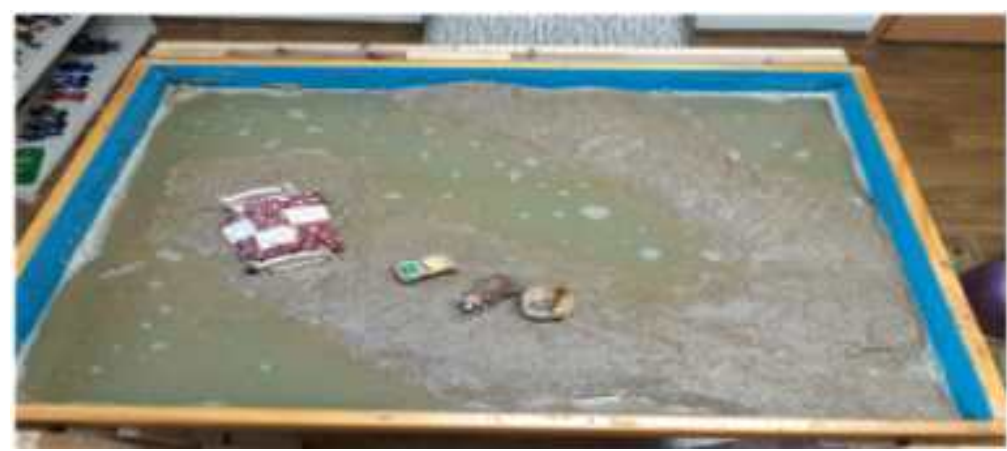

Sand picture \#5 
Journal of Symbols \& Sandplay Therapy, Vol.11 No.2.

dipping in and lifting out of the unconscious so as not to be overwhelmed. The ruined house could represent the client's repressed autonomy and independent as well as lack of emotional care at home or be a symbol of the negative mother archetype in the collective unconscious.

\section{B. The Fighting Phase}

\section{Session 6}

The client kneaded wet sand for a long time without saying a word and made an upside-down U-shaped structure with it. Then she poured water inside the tray once again. Pointing at the calves, the client said, "They didn't like their home so they moved to the mudflat. There's nothing to eat at home so they're looking for food in the mudflat." The mudflat is an expansive field of mud near the coast. Sediments in water become deposited in leveled areas where water is slow in current to form mudflats. So many creatures live fiercely inside the mudflat, ceaselessly moving around and finding food. Moving to the mudflat because there is nothing to eat at home signifies the client's moving away from an emotionally-barren home to a place that provides her with necessary nurturing. In other words, it represents her independence and ego development. The client took an active measure to move to the mudflat because she does not like home. Actively trying to satisfy the needs in her life is connected to the fact that she has now gained the energy to verbally express herself instead of simply becoming irritated at the situation. The mother reported that around this time the child could tell her peers things like, "Why're you only blaming me!" or "Don't show off." Moreover, she slept over at a friend's house without the mother. Number four is a feminine number, or the

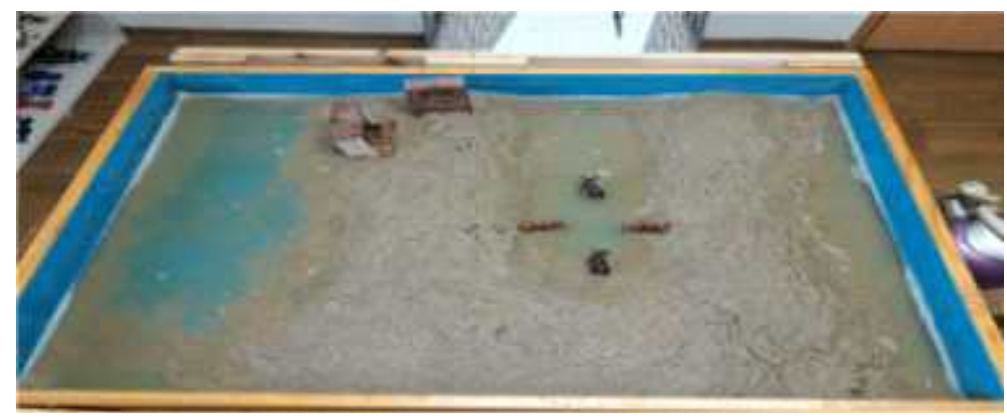

Sand picture \#6 
number of feminine energy. The quaternity of calves could represent that while developing consciousness, the client can also develop her feminine aspects (Eastwood,2006).

\section{Session 7}

"There was a lot of water because of flood, so [no subject] built a house again on the mudflat. It's good that the mommy duck isn't here because she nags too much." With this, the client grinned. The she pointed to the mother duck and said, "The mommy duck is trying to eat bread. And when there's too much water because of flood, you can scoop it out with a bucket."

Using wet sand is the ego intention to deal with emotional aspects (Ammann, 2001: Grubbs, 1995). Water can represent the ocean, symbol of the unconscious. Children who had been abused in particular use a lot of water to represent flood or play with completely-soaked sand (Grubbs, 1995; Mitchell, 2012). The client seemed to pour out her repressed emotions onto the sand while kneading it. Moreover, she appeared to in the process of recovering her lost autonomy by being immersed in the play with sand for a long time without a word.

The duck is the mediator between sky and water (Cooper, 1978). For the client, the duck could symbolize the ego-Self connection. But given the baby duck and the mother duck eating bread, perhaps there is the need for more care.

The U-shaped sand structure may represent nurturing containment, though not yet fully protected. The child's comment about excessive water and scooping it out with a bucket could represent excessive repression on the part of the mother. Scooping water out with a bucket seems to signal the client's discovery of her lost autonomy and independence, which is positive. After this session, the mother reported that the client, who was unable to sleep alone, said she wishes to have a separate room of her own as her friends have their own rooms. Children reinforce their ego by establishing peer relationships at school. During this period, positive development enables children to use their energy on daily and intellectual activities, through which their ego develops diligence and social adaptability (Choi, 2006). Wanting to have a space of her own seems to be a representation of her desire to separate from her mother. And the fact that she is now more interested in what her peers do could signify that her consciousness is developing. 


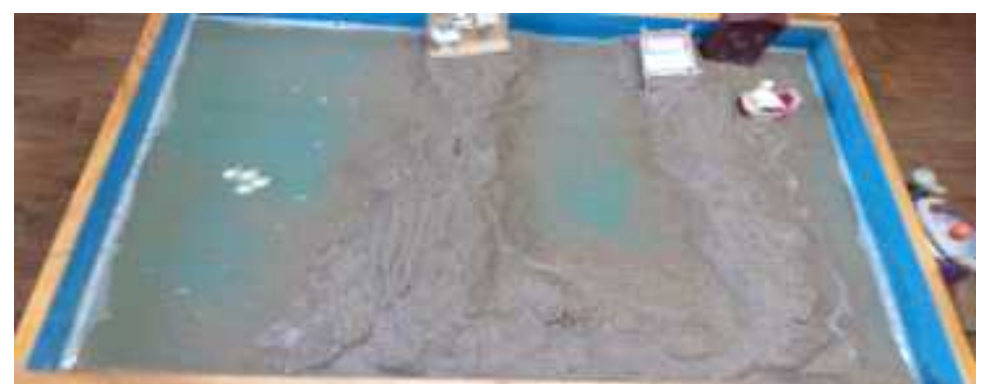

Sand picture \#7

\section{Session 8}

"[The ducks] moved because water filled up. The ducks and the penguin are friends. On the left is a sand island, and on the right is a dike that's connected." Then she looked at the therapist and paused. As if in a deep thought, the client looked down and stroked the U-shaped mound. "I've never helped my friends, but my friends help me." With her face turning slightly somber, she said, "I have hard time keeping up with my studies, but my mom says I have to get good grades." Then she touched the sand and smiled slightly, saying, "It's good that there's a new house, but the sand feels a little rough."

Using water in sandplay therapy is an intentional act by the ego to take part in the unconscious both directly and minutely. Contacting water entails the trust in contacting the unconscious, and the fluidity of water guides the ego to the Self and brings new energy (Turner, 2005). In sandplay, water erodes the sand and makes it into mud, thereby blurring boundaries (Turner, 2005). Flood that appears in the middle phase of a sandplay process represents the meeting with the unconscious and serves as a prelude to a rebirth after death (Turner, 2005). An adequate amount of water could represent rebirth; it is usually represented by the life-giving water, well, drinking water, river, sea and baptism. Psychologically, this is the ego's intentional behavior to go towards the unknown. The nourished ego is moving towards its domain (Turner, 2005). Now the client is achieving ego-development through the experience of sandplay.

Penguins live with large groups of other penguins. Even chicks gather and form groups of their own when they are partially grown. The appearance of a penguin in this sand picture 
could represent the client's adaptation to her peer group. It signifies the beginning of her sociality, and perhaps we may be able to see her moving from the world of maternity to the world of paternity. Right after this session, the mother reported that the child told one of her friends not to show off. The mother was amazed to see the client expressing her emotions verbally. The U-shaped sand structure is now looking closer to a circle. This may imply that centralization is taking place in the client's inner world and be a prelude to her ego development.

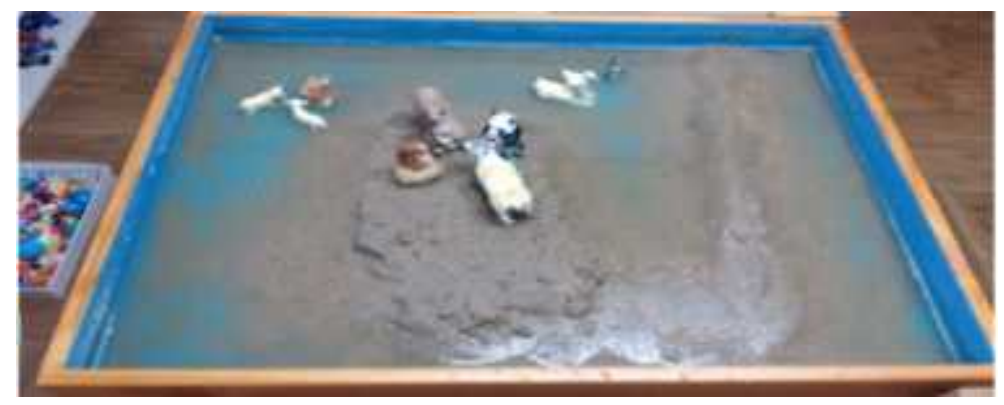

Sand picture \#8

\section{Session 9}

"The daddy duck is working hard, and the older sister duck is studying. The mommy duck is watching the baby duck sleeping. The baby duck is sleeping on the bed." The client explained the while the older sister duck is studying hard, she herself finds studying very difficult. It appears that she sees herself through the studying duck. The client struggled to keep up with mathematics and science, especially after going up to fifth grade. The mother duck is watching the sleeping baby duck. Next to the bed are the father duck working and the older sister duck studying. This orientation seems to indicate the client's wanting to receive care from her parents. The wet sand above and the blue bottom below show the division of earth and water above and below, which could mean that separation or individuation in occurring within the mother-child unity. Although the bottom of the tray is still filled with water, there is less amount than before. In sandplay, water erodes the sand and makes it into mud, thereby blurring boundaries (Turner, 2005). An adequate amount of water could represent rebirth; it is 
Journal of Symbols \& Sandplay Therapy, Vol.11 No.2.

usually represented by the life-giving water, well, drinking water, river, sea and baptism. Psychologically, this is the ego's intentional behavior to go towards the unknown. The nourished ego is moving towards its domain (Turner, 2005).

In sand tray the upper realm signifies sky, consciousness and masculine energy whereas the bottom realm represents unconsciousness, the underworld and feminine energy. The duck family in the client's sand picture is in the conscious realm. This could mean that only when children are provided with care within a stable family relationship in the conscious realm can they feel emotionally stable and achieve development (Turner, 2005).

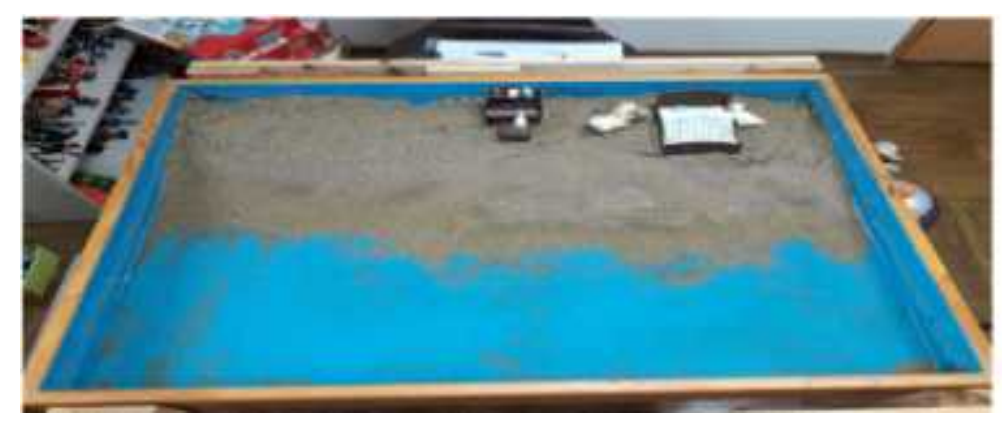

Sand picture \#9

\section{Session 10}

The client described that the rabbit came to the deserted island because it wanted to be alone. It is calling a friend, and later will become sad because the island will be collapsed by the waves.

The monkey symbolizes impudence, impatience, curiosity, evil tricks, and lowly instinct (Cooper, 1978). The reflection of the monkey sitting on the table can be seen in the mirror next to it. This orientation shows that the client is in the process of facing her instinct in the unconscious. The mother reported that the client is gradually beginning to tell stories of her friends, doing things on her own, and controlling herself to yield to her friends. It seems that centralization is taking place, and the mother's testimony reveals that the client's ego development is taking place. The staircase-shape structure inside the circle shows the stage in which the child becomes conscious of her inner world. Centralization helps to reach a higher 
level and access conscious awareness (Turner, 2005) or, in other words, shows the process of Self constellation for the child.

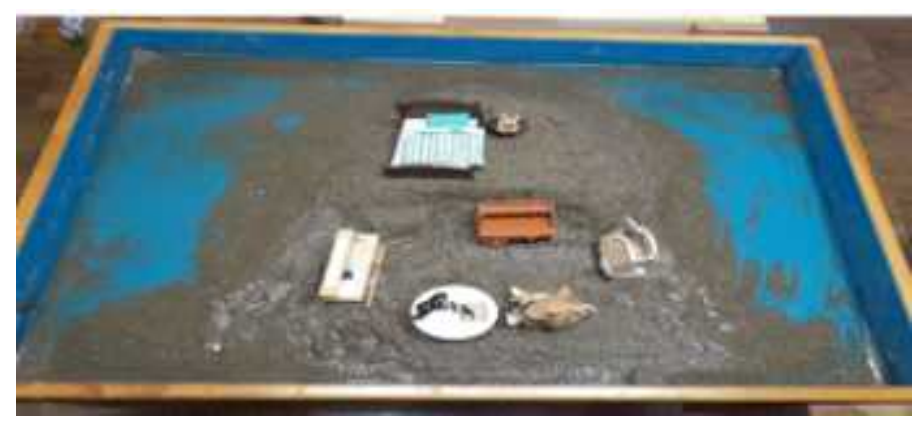

Sand picture \#10

\section{Session 11}

"[The squirrel] came over to [its] friend's house. This is an island. The monkey lives in this island so that it can play in the water. There are lots of bananas here. The parents aren't here; they live in Seoul. [The monkey] called the squirrel friend and asked [it] to come over. If it was me, I'd be scared to live here alone. The flower in the box is for mom." Then the client looked at the therapist and said, "Math has gotten difficult since fifth grade. I like to draw."

Centralization is clearly taking place in this sand picture. Eliade (1990) explained the center is where divinity is. The sand tray would function as a special location in which divinity is realized. The way the client mixed sand with water and gathered the mixture towards the center of the tray felt like a divine ritual. It also appeared that the movement of her psyche was focused on the center.

Although the sand picture is not yet forming a mandala with a focus towards the center and perfect four cardinal points, it seems to foretell the manifestation of the integrated conscious in the near future. The ideal state would be to achieve wholeness by overcoming the negative mother archetype and separating the conscious and the unconscious. Using and mixing water with sand seems to indicate a positive energy of development, who is now able to break free from the dark shadows of the mother and unafraid of descending into her unconscious. The 
Journal of Symbols \& Sandplay Therapy, Vol.11 No.2.

faucet and the shower head appear to indicate a process of purification. The flower represents energy at the center moving towards outside; though the flower in the box is not yet evident, it could represent the potential manifestation of the Self (David,1993). The stairs represent ascendance, transcendence, and a movement towards a new existential level. The stairs inside the circular formation is a representation of the development of consciousness, once again showing that the client's ego is developing and becoming conscious.

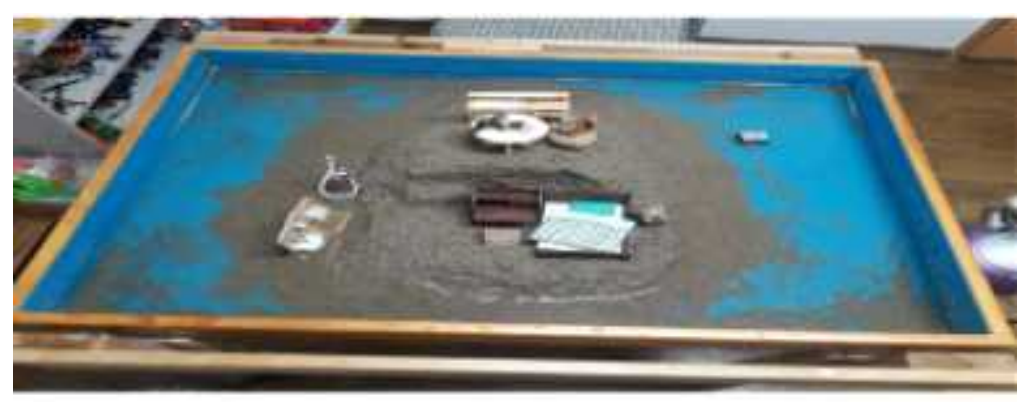

Sand picture \#11

\section{Session 12}

"[The animals] on the left were poor at first, but they worked hard and became rich. [The animals] on the right were first rich but they used up all the money and became poor. This is a deserted island. The left side is happy and the right side is sad. I'm friends with Jin-ah. Sometimes we get along and sometimes we don't. Jin-ah likes to run around and play. I like to sit down and do quiet plays.

An expansive land is stretched out in the left half of the sandtray, which is the unconscious realm, and in it is a round table and a sofa that represent the desire for relationships. They perhaps represent the beginning of a deep relationship with the unconscious. The bigger piece of land in the left near quadrant and the smaller piece of land in the right near quadrant seem to be an expression of the mother-child relationship experienced by the client during childhood. This sand picture seems to show that the client's ego, which had been dysfunctional, is being nurtured by the Self for a safe psychological separation from the mother and therefore can develop into a healthy ego. A child's ego that was not nurtured by the Self is either inflated or needy or ego and cannot function properly (Neumann, 2004). 
Expressions such as "rich," "poor," "friends whom I get along with," and "friends whom I don't get along with" may represent the manifestation of the opposites: the negative mother archetype and the positive mother archetype. These statements also show her ambiguous feelings towards the mother and the beginning of a psychological separation. That she sometimes gets along with her friends and sometimes doesn't seem like a statement indicating that she has obtained insight about herself. When she is able to integrate those insights, she would learn how to express herself appropriately within interpersonal relationships. The oven is the symbol of transformation. The oven contains, and transformation occurs when the food contains inside is cooked. Just as food undergoes a transformation by being cooked in the oven, the client has to integrate the opposites: rich and poor, friends with whom she gets along and doesn't, etc.

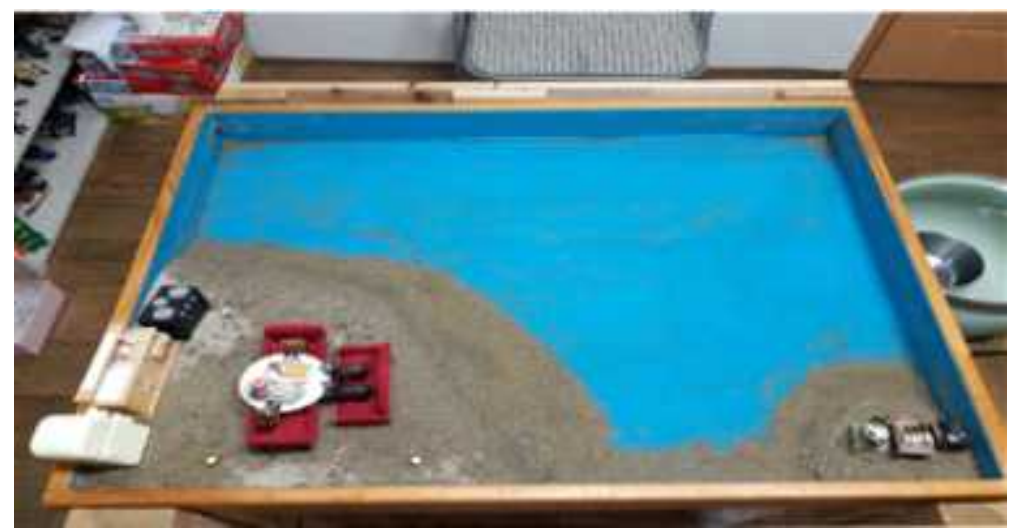

Sand picture \#12

\section{Session 13}

"Children here used to be rich. This is an island. They were playing in the sea but came here because of the waves. Only this family lives in this house. This is a deserted island on the right. They came to this island too, but they threw them out because they were here first. The children on the right side are friends."

The world that the client created in this session is a deserted island. Island is a place of isolation and loneliness and at the same time a safe haven from the sea of chaos (Cooper,1978). With the two opposing symbolisms, the island could be a paradise in which the client wants to 
Journal of Symbols \& Sandplay Therapy, Vol.11 No.2.

stay forever or a land of restriction that disrupts her development towards a new world. This signals client's moving away from the mother-child unity, which is symbolized by the uroborous, and thereby gradually being separated from the world of the mother and transitioning to the world of the father. The client's unconscious materials related to the mother are probably ambiguous or confusing. This is probably also related to overcoming the negative mother archetype, which overprotects and therefore disrupts the development of an independent, autonomous ego.

Cats represent the feminine mystery as well as the positive and creative aspects (Ackroyd, 1993). It also symbolizes patience, desire and freedom (Cooper, 1978). Food is a symbol of peace and resolution of discord as well as vitality and friendship (David, 1993). By restoring her feminine aspect, which was repressed by the mother, the client would be able to gain the strength to engage in good peer relationships and express her emotions in a positive manner.

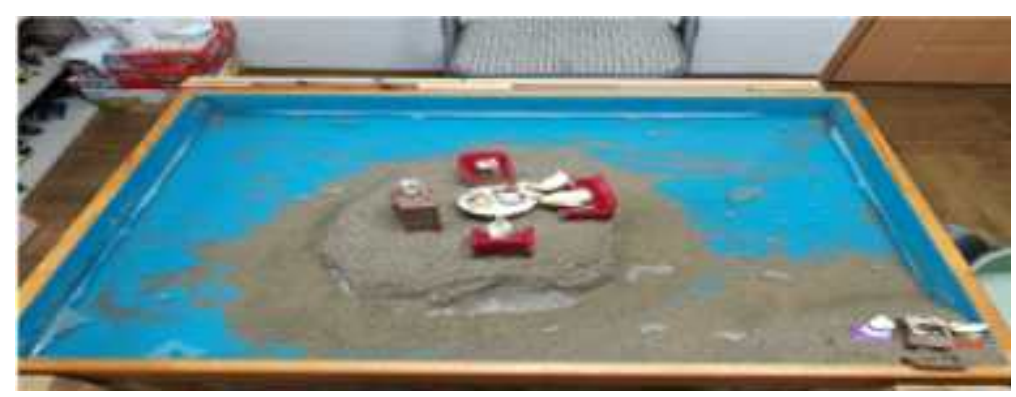

Sand picture \#13

\section{Adaptation to Everyday Life}

\section{Session 14}

"There are only children here. Mom and dad are somewhere else. This place is a deserted island. There are only children in the right side, too. Mom and dad went to work."

It looks like the client has achieved ego development and reached the stage of becoming independent from the mother. There are only children in the deserted island while the parents are at work. Moreover, there is plenty of food to eat, there are enough resources to nurture and care for the child. 


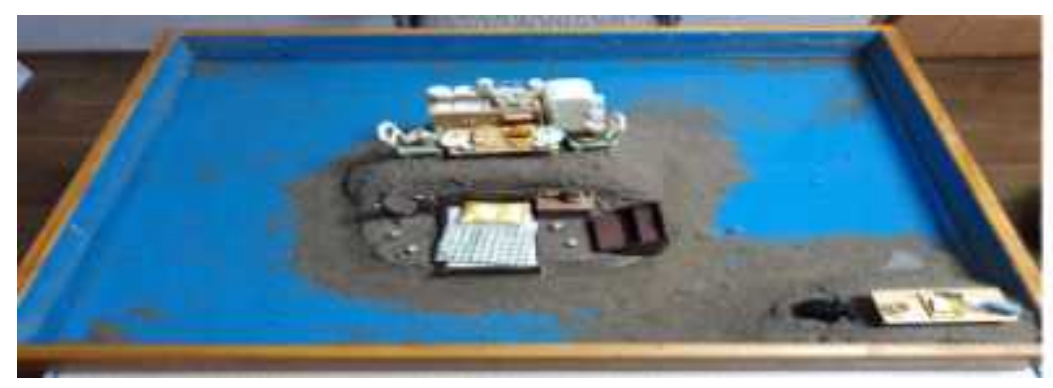

Sand picture \#14

\section{Session 15}

“This is a park. They're eating with friends. It's the duck's birthday. They're having a birthday party."

The center of the sand tray is an important part of the client's psyche and also the center of the Self. The act of centralization occurring at the center of the tray is related to the Self archetype and therefore is of a paramount important in sandplay therapy (Turner, 2005). The sand mount at the center looks like a divine place where the client would build a relationship with her unconscious as well as the outer world. The divine space facilitates entry into the divine time. Eliade (1990) explained the center is where divinity is. The sand tray would function as a special location in which divinity is realized. And the way the client gathered sand towards the center of the tray seemed to indicate that the movement of her psyche that was focused at the center.

The duck connects sky and earth. For the child, this could indicate the connection between her ego and Self. Birthday parties are held to celebrate birth. A birthday party with friends allows joyful experience with peers. It also symbolizes a new birth. Therefore the birthday party

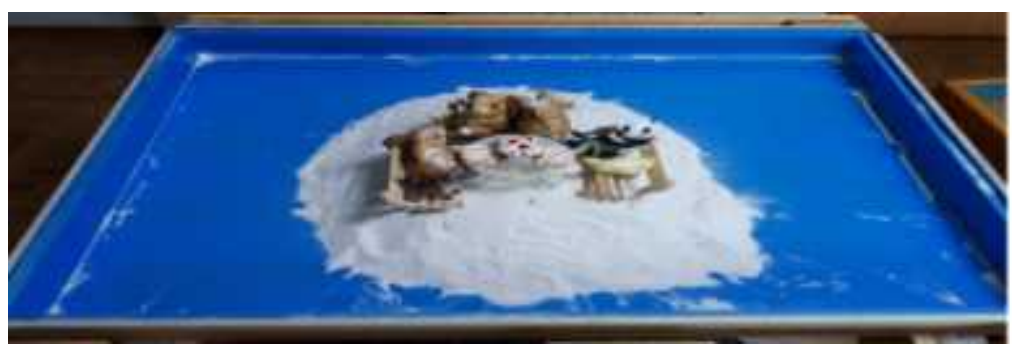

Sand picture \#15 
Journal of Symbols \& Sandplay Therapy, Vol.11 No.2.

could be a ritual celebrating the child's being born as who she genuinely is. Adolescents want their children to be indifferent. The experience of accepting differences must be acquired through peer relationships. Only then will the adolescents discover their own identity and accept the differences of others.

\section{Session 16}

"My friend borrowed money from me but won't pay pack. I want to show her. My mom takes me to school. I still can't go to school alone on the bus, because the bus might drop me off somewhere else [other than school]. I don't like my mom when she nags, but I like her when she doesn't nag. These children in the sand tray met at the park and walked home together. They get along with each other. There are friends that you can't get along with. I like quiet plays, but other kids like to play tag. I play [tag] even when I don't want to because other kids might get offended and won't play with me... But when I actually do it, it's fun. (Smile). I was ostracized in first and second grade. My friend's mom told her not to play with me because I have lice in my hair. I want to live in an apartment but I have to live in a house because of the dog." The client experiences joy doing things she does not want to but does anyway so as not to become ostracized. In addition, she wants to live in an apartment where she can easily make friends but she accepts the fact that she has to live in a house because of their pet dog.

A giraffe is sitting at the center of the tray. The giraffe symbolizes the ability to see things from far and high above (Cooper,1978), which is related to the ability to perceive a situation objectively. That the client has developed the ability to view the world is associated with her emotional transformation and development. Animals that are tall or have a long neck symbolizes divinity or spirit, or the relationship with the inner world. After creating this sand picture, the child began to talk rather frankly about her family and her own emotions. Given that she used to avoid talking about these subjects, it seems that her psyche has undergone a change. The honest self-report about how she felt her in the peer relationship indicates the development of self-awareness as well as an objective view of the outer reality.

It appears that the client's inner world-the domain of the unconscious - is in 
communication with the outer world - the domain of the ego-through sandplay. The mother's overly caring and repressive attitude disrupted the client's growth. However, now the client has developed a sense of awareness through which she can see herself objectively, just like the giraffe. But the house on the right implies that the client still needs nurturing and nourishment.

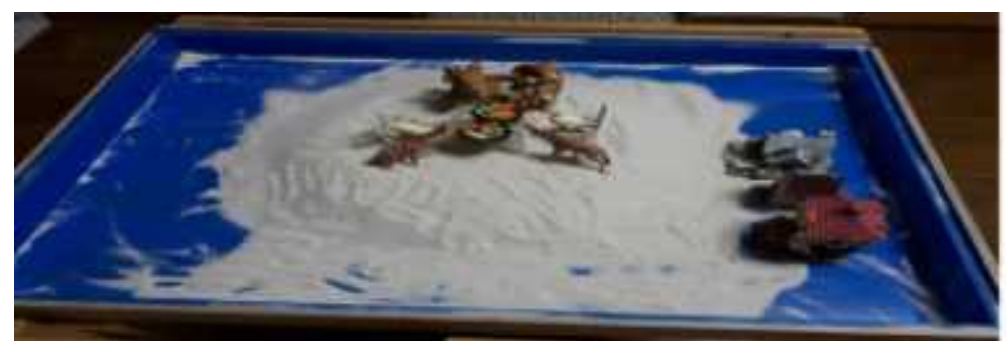

Sand picture \#16

\section{Session 17}

"This is a countryside village. The bear family and their friends are faming. The duck is making rice cake because there's nothing to eat. It's a nice feeling."

The symbolic representation of the elephant stems from the important role that it plays in general life and the industry. Traditionally, elephant served as a means of transportation by monarchs and royal figures. It also symbolizes victory over death and the dignity and wisdom of the old. For the child, the elephant could mean that she has developed the energy to do things on her own rather than depending on her mother.

The tower can be a symbol of the phallus. For women, the tower symbolizes the animus. For the client, the tower may suggest that she has developed the ability to be confident in her behaviors and in expressing her opinions.

City is a symbol of the Self. Going into the city symbolizes the intention or the necessity to explore the unconscious and become familiar with what is inside (Ackroyd,1993). The cilent is perhaps ready to become adapted to her outer reality.

The bear, which is masculine in its shape and form, symbolizes bravery and energy among native North Americans and the Chinese (David, 1993). For the child, the bear appears to be a symbol of ego development, i.e., she may have developed the energy to make her own decisions. 
Journal of Symbols \& Sandplay Therapy, Vol.11 No.2.

The arrangement of the houses form a village. The act of farming tells that harvesting will take place in the future. We may be able to see the achievement of certain tasks or obtainment of self-esteem in the client's outer world.

The four bears and sixteen houses in the last sand picture are strong symbols of the energy of integration. Number four symbolizes the four principal lunar phases, four seasons, and the four elements of the conscious. It also represents the four basic aspects experienced through the act of becoming conscious and a boundary where something new begins. The number sixteen is also associated with the number four, as four times four equals sixteen. It is a symbolism for the realization of a complete differentiation of the four aspects of the conscious (Abt, T, 2005/2007). We can expect the child to separate from the primal unity with the mother, develop a new ego-consciousness, and safely carry out the next development task. The symbols seem to say that the client has begun the journey of discovering her identity.

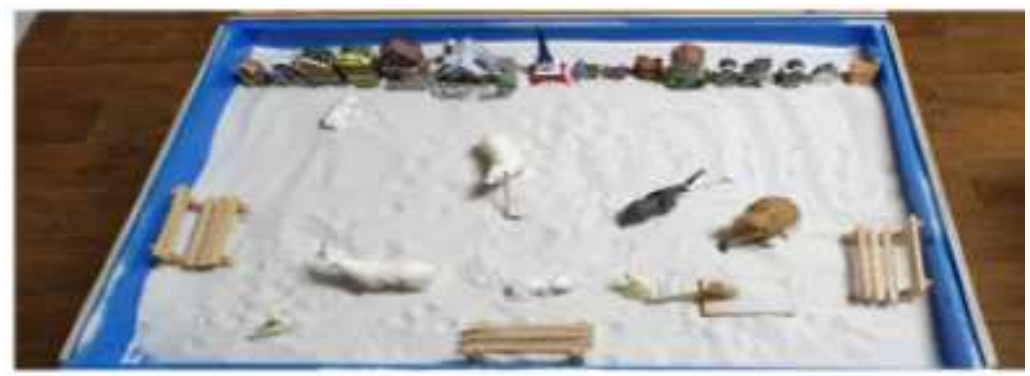

Sand picture \#17

\section{CONCLUSION}

The client received a total of 17 sessions of sandplay therapy and created a sand picture in every session. Through her sandplay process, the client experienced inner transformation and ego development. Amid the chaos of her undifferentiated ego, which is attributable to attachment trauma, the Self became differentiated. She also developed an ego function that enabled her to clearly express her opinions to her peers. 
The first phase of ego development according to Dora Kalff (1980/2003, as cited in Turner, 2009) is the animal-vegetative stage. The client's first five sand pictures belong to this stage. From session one to session five, the client vented and resolved her inner anxiety and conflict that were in a state of chaos by mixing sand with her hands. She showed the process of bringing healing to the chaos and disorder in her unconscious.

Second is the fighting stage. From session six to fourteen, the child experienced psychological rebirth and resolved inner conflicts through regression. Though not fully complete, centralization took place in her sand pictures. This process is probably connected the journey to restore her ego that was damaged due to repression from the mother. In addition, she continued to express the desire to achieve positive growth and bring healing to her repressed emotions, which are attributable to the lack of emotional care from the mother. In this process, the child struggled with the inner energy to resolve the inner conflict in her unconscious. Through the fight between the old and the new, the child achieved new growth and consequentially established new relationships. In her outer reality, she was able to clearly deliver her opinions and intentions to her friends and her mother by saying: "Don't show off. Why do I have to do that?" and "I want to have my own room."

Third phase is adaptation to outer reality, which was shown in sessions 15 to 17 . In session 15 the client said, "These children in the sand tray met at the park and walked home together. They get along with each other." It was a sand picture depicting a birthday party with friends. In her outer reality, too, the child build relationship with her peers and verbally expressed her intentions. In session 17, in which the last sand picture was created, number four and sixteen, which symbolize the birth of new consciousness, appeared through figures. This particular sand tray hinted the energy for a new beginning and implied that her energy flow is resolving her inner conflicts and problems. And the use of food, a symbol of nurturing, showed the nurturing and caring aspect of the Self energy.

In the later part of her sandplay process, the client's sand picture showed images of the mandala which included squares and circles, a symbol of totality and wholeness. The pictures significantly displayed the integration of instinctive energy through sandplay. By bringing integration to the state of chaos and emotional deficiency, she achieved growth. And by 
Journal of Symbols \& Sandplay Therapy, Vol.11 No.2.

developing the ego and enhancing her relationship with it, the client developed social skills and therefore was able to form more intimate relationships in the outer reality. The child overcame the problems of a damaged mother-child attachment and emotional regulation, and thereby developed the will to bring improvements to her problem behaviors. In fact, the mother reported that the child wanted to be alone, said she can go to school by herself, and demanded for her own room. There were also changes in the client's peer relationships: She slept over at one of her friend's house. She separated with the mother and went into the relationship with her peers. By forming a relationship with the therapist who contained her with patience, the child became emotionally stable and therefore became adapted to her life in the outer social environment and resolved conflicts within. As a result, she developed the ability to accept herself and others as well as to regulate her emotions. She also showed positive changes, such as becoming more adjusted to school life. For such positive changes to last, the child and also the parents need to receive necessary support. But sometimes the parents want to terminate therapy earlier than necessary, and, unfortunately, there is not much therapists can do in this situation. This case served as an opportunity to realize the need for sandplay therapy to provide a "free and protected space" in which therapeutic experience can take place so as to facilitate ego development in a child.

\section{References}

Abt, T. (2005/2007). Jungian psychological picture interpretation. (Translated by Lee, Yoo-kyung.) Seoul: Institute of Analytical Psychology

Ackroyd, E. (1993/1997). The dream dictionary. (Translated by Kim, Byeongjun.) Seoul: Korea Psychotherapy Institute.

Ammann. R. (2001/2009). Jung psychological sandplay therapy. (Translated by Lee, Yoo-kyung.) Seoul: Institute of Branch Psychology.

Bae, J-Y. (2012). The mediating effect of child personality traits in the influence of parent-child attachment degree on friend relationship. Dankook University Graduate School of Education Master's Thesis.

Choi, K-S, (2006). Child development psychology. Seoul: Gyomunsa. 
Cooper, J. C. (1978). An illustrated encyclopedia of traditional symbols. New York: Thames \& Hudson. (Trans. Korean into 1994).

David, F. (1993). The language of symbols. (Translated by Choi, Seung-ja.) Seoul: Munhakdongne.

Eastwood, P. S. (2006). Sandplay therapy and symbol of numbers. (Translated by Jeong, Jeongoon et. al.) Seoul: Hakjisa.

Elkid, D., \& Weiner, I. B. (1978). Development of child. New York: Wiley \& Sons.

Eliade, M. (1990). Image and symbol: Studies in religious symbolism. (P. Mariet,Trans.). Princeton, NJ: Princeton University Press. (Original work published 1952)

Grubbs, G. (1995). A comparative analysis of the sandplay process of sexually abused and nonclinical children. The Arts in Psychotherapy, 22(5), 429-446.

Jang, M-K. (2017). Analytic psychological sandplay therapy. Seoul: Hakjisa.

Jang, N-E, (2010). Sand play therapy on depression, self-esteem and interpersonal relationships in ADHD adults effect. Namseoul University graduate school master's thesis.

Jung, C. G. (2006). Man and Culture. C. G. Jung Institute of Korea. Translated Works of the Collected Works of C. G. Jung (Vol. 9). (Translation Committee for the Works of C. G. Jung Institute of Korea, Trans.). Seoul: Sol Publishing.

Kalff, D. M. (1980). Sandplay: A psychotherapeutic approach to the psyche. Santa Monica, California: Sigo Press.

Kang, N-J. (2008). The effects of marital conflict and social support perceived by children on self-esteem. Ewha Womans University Graduate School of Education Master's Thesis.

Lee, E-C, (2011). A study on the influence of sand play on children's self-development stage, self-esteem and sociality: Focused on gender difference. Master's thesis at the Graduate School of Gachon Medical University.

Lee, S, (2015.) The effect of sandbox play on communication between mother and child with unstable attachment. Daegu University Graduate School of Rehabilitation Science Master's Thesis.

Lee, Y-G, (2019). A qualitative study of maternal symbols and maternal-child relationships in the sand play treatment process of children who experienced relationship trauma. Hanyang University Graduate School doctoral dissertation.

Lee, Y-K, (2004). Archetypes and myths. Seoul: Organo.

Neumann, E. (2004). Ursprungsgeschichte des Bewusstseins. Dusseldorf: Walter. (Trans, into Korean in 2007).

Park, E-H, (2012). The effect of structured group sandplay therapy on children'sself-esteem and emotional intelligence. Myongji University graduate school master's thesis. 
Journal of Symbols \& Sandplay Therapy, Vol.11 No.2.

Park, H-G, (2011). A study on the symbol of water from an analytical psychological perspective. Sand Play Therapy Research, 7(2). 59-72.

Park, H-G, (2012). Chaos, death, and rebirth in children's sand play treatment. Doctoral dissertation at Myongji University Graduate School.

Robert, A. J. (2006). Femininity "She" read as a myth. (Translated by Go, Hye-kyung.) Seoul: Dongyeon.

Turner, B. A. (2005). The handbook of sandplay therapy. Los Angeles, CA: Temenos Press. 
상징과모래놀이치료, 제 11 권 제 2 호

Journal of Symbols \& Sandplay Therapy

2020, 12, Vol. 11, No. 2, 113-141.

doi https://doi.org/10.12964/jsst.20008

\title{
부모-자녀 및 또래 관계 문제를 가진 아동의 모래놀이치료 사례연구
}

\section{Children with Parent-child and Peer Relationship Problems: \\ A Sandplay Therapy Case Study}

\author{
박 윤 수 $^{*}$ \\ Park, YounSoo
}

\begin{abstract}
$<$ Abstract $>$
This study aimed to heal the experience of attachment trauma and promote the self-development and growth of children through sandplay therapy. We conducted 17 sessions over 6 months with a school-age child, and we include 17 sand photos from these sessions. This child had not separated from the mother because of unstable attachment, which delayed their self-development towards autonomy and independence. The child could not express their feelings and intentions voluntarily and had a strong tendency to depend on the mother, which limited the experience of positive communication with other children at school. In improving self-relationships along with self-development while playing with sand, the child improved their ability to form intimate relationships. Through the experience of the relationship with the therapist, the child resolved and adapted to the conflict in their social environment while maintaining stable emotions. As a result, the child showed positive changes in their ability to accept themselves and others, developed emotional regulation, and improved school adaptation.
\end{abstract}

Keywords : early relationships, sandplay therapy, ego development, attachment

* 남서울대학교대학원 아동복지학과 박사수료 (youn4992@hanmail.net) 
Journal of Symbols \& Sandplay Therapy, Vol.11 No.2.

\section{I. 서 론}

초등학교 저학년 시기의 아동은 가정에서 학교로 사회적 관계망이 넓어지게 되면서, 다 양한 사회적 적응을 요구 받게 된다(Elkind, 2000). 또한 이 시기의 아동은 신체적·심리적 발달과정에 있으며 자아를 형성 및 성장시키고, 또래 관계를 맺는 등 여러 가지 발달과업 을 수행하고 습득해야 한다(강나정, 2008; 김영아, 2009). 특히 초등학교 고학년부터 사춘기 를 겪기 시작하면서 독립적인 성향이 강해져 부모의 통제에서 벗어나려고 시도하며 가정이 외의 장에서 또래와 같이 하는 활동량이 반 이상을 차지하게 될 정도로 또래가 중요한 사 회적관계의 중심이 되며 또래관계를 통해 사회적, 대인관계 기술을 습득하고 자아정체감, 가치, 신념 등을 형성시킬 뿐 아니라 성역할, 도덕성, 자아개념 형성에도 영향을 미치게 된 다(Furman, 1982). 그러므로 초등학교 고학년의 또래관계의 영향력이 더욱 커짐에 따라 아동 이 또래관계를 어떻게 인식하고 있는지 파악하는 것도 매우 중요하며 또래관계에 영향을 미치는 요인들을 탐색해 볼 필요성이 있다고 하겠다.

또래란 나이, 성, 학년 수준에서 비슷한 특성을 가지고 정신적, 신체적 발달과 행동이 유 사한 아이들로서 사회적으로 동일시되어지는 대상으로 정의하였다(이호선, 2001). Rubin에 의하면 생애 초기의 아동은 신체적으로나 심리적으로 부모에게 많이 의존하며 부모와의 관 계에서 많은 것을 배워 나가지만 차차 성장함에 따라 역량과 독립심이 발달하게 되고 보다 유동적이며 넓은 범위의 환경과 상호작용함에 따라 또래가 중요한 존재로 자리 잡게 된다 고 하였다(유은아, 2005). 또래집단은 비슷한 연령대의 친한 또래들의 소집단으로 규정할 수 있으며 때로는 반드시 또래는 아니더라도 연령이 비슷한 사람들의 집단을 의미하기도 한 다. 청소년기에는 대다수의 청소년들이 소집단이나 또래집단의 구성원이 되기를 원하는데, 또래 집단은 그 구성원에게 고유한 안정감과 지지를 부여함으로써 청소년들의 불확실한 자 아의식에 편안함을 주며 또한 또래집단 내에서의 사회적 상호작용을 통해 행동규범과 가치 를 발달시킨다(이희연, 1994). 아동은 또래들과 어울림으로써 직접적으로 충족감을 느끼고 또래를 통해서 자신의 갈등이나 열등감을 표출하고, 다른 아이들도 자신과 똑같은 문제들 이 있다는 것을 알게 될 때, 마음이 편안해지며, 자신의 건강이나 죄의식이 감소되기도 한 다. 또래들과 원만하게 어울림으로써 내면적 성숙과 사회적 적응력, 활동력이 개발될 수 있 는 것이다(김영미, 2000). Azmitia는 또래관계가 아동발달에 있어 다음과 같은 중요한 기능을 담당한다고 하였다(이승희, 2007). 첫째, 아동은 또래와의 상호작용을 통해 보다 큰 사회관 계망 내에서 스스로의 정체감을 발견한다. 둘째, 아동들은 또래관계를 통해 타인의 관심사 에 대한 이해, 타인과의 의사소통하는 능력 등을 포함한 사회 인지적 기술의 기초를 발달 시킨다. 셋째, 또래들은 신체적. 인지적 기술을 습득함으로써 타인의 인정을 받게 된다. 넷 째, 또래 간 상호작용은 부모가 도움을 주지 못하는 친숙하지 않거나 위협적인 상황에서 
정서적 지지를 제공한다. 이처럼 아동에게 또래관계는 아동기 발달에 중요한 기능을 담당 하고 있다.

이러한 또래관계에 영향을 미치는 요인에는 부모와의 애착이 있다. 애착은 자녀와 양육 자간의 친밀하고 강한 정서적인 유대관계로써, 애착형성과정에서 양육자의 민감한 양육행 동에 따라 애착의 질이 달라진다(Bowlby, 1969). 아동의 성격 특성은 부모의 애착에 의해 가 장 많은 영향을 받는데 부모가 자녀에 대해 무관심 하거나, 방임하거나, 통제력을 행사하는 데 어려움이 있거나 냉담한 태도를 보이는 것 등은 자녀의 부적응에 영향을 미치는 중요한 요인으로 작용한다. 따라서 부모와의 애착이 불안정한 경우, 자녀는 자기만족 수준이 낮고 (Collins \& Read, 1990), 의사소통에도 문제가 있으며, 대인관계에서 갈등을 처리하는 문제를 경험할 때 만족스런 문제해결을 하지 못 하기도 한다(천귀순, 2003).

애착은 어머니와의 반복된 상호작용 경험이 성인이 된 이후에 애착유형의 발달에 영향을 미치며 자녀와의 애착관계 형성에 영향을 미치게 되는 것으로 애착이론가들은 이를 애착의 지속성 이라 부르며 안정 또는 불안정 애착모자가 형성 되게 한다고 보고하였다(장휘숙, 1997; Feeney, 1995). 이렇게 형성된 불안정 애착 모자는 안정 애착 모자에 비해 공감능력이 부족하고(Barrett, 1987; Eisenberg, 1989) 상대방에게 최소한의 주의를 기울이거나 과도하게 주의와 접촉을 요구하며(김성애, 2008; 윤선모, 2011), 이 과정에서 언어적 비언어적으로 부 정적인 정서표현을 하기 때문에 모자의사소통에 어려움을 겪는다(김미나, 2008; 오지현, 2010). 모자 의사소통에 영향을 미치는 요인으로는 부모의 양육태도, 가족구조, 사회경제적 배경 자녀의 연령과 기질 등 여러 가지가 있지만 그 중에서도 애착은 모자 의사소통의 원 인이자 결과로 까지 작용 한다. 아동의 부모자녀와의 관계 또래와의 의사소통의 어려움은 이러한 부모의 양육태도가 많은 영향을 미치며 부모와의 불안정 애착은 아동의 자아 발달 을 저해 하는 요소가 될 수 있다.

아동에 있어서 자아의 발달은 무엇보다 중요하다. 의식의 중심이며, 주인인 자아의 탄생 은 세상의 창조를 이루는 발아로, 한 사람으로서의 주체성을 찾아가는 시작이라 할 수 있 다. 아동이 창조를 이루고 투쟁을 통해 자아를 성장시키고 이후 통합의 과정에 이르게 됨 은 중요한 과업이라 할 수 있다. 한 인간은 획일화된 발달과정을 거치지 않고 그 자신의 독특한 개별화를 이루게 됨으로서 긍정적 자아 존중감을 형성하여 가치 있는 자기 지각과 세상 속에서 온전한 자신으로 살아가게 된다. 이러한 자아의 성장과 발달을 이루는 아동기 는 자아의 발달을 통해 자신을 긍정적으로 평가, 지각하는 자아존중감과 사회성 발달에 중 요한 부분을 차지한다. 아동이 자신을 어떻게 지각하고 있는가에 따라 타인을 바라보는 모 습에서도 보다 긍정적이거나 부정적인 태도를 나타낸다. 따라서 자아존중감은 타인과의 관 계 및 또래와의 관계를 형성 하는데 있어서도 영향을 미친다. Cooper smith(1967)는 자신을 가치 있게 보고 자신에 대한 긍정적 평가를 바탕으로 타인과의 상호작용 및 사회 적응과 
Journal of Symbols \& Sandplay Therapy, Vol.11 No.2.

깊은 연관이 있는 자아존중감은 자신에 대한 개인적인 평가로서 긍정적 이거나 부정적인 태도로 표현되며, 자신의 능력, 중요성, 성공, 가치 등에 대해 스스로 어느 정도 믿고 있는 지를 나타낸다고 하였다. 자신의 가치를 인정하고 신뢰를 갖는 높은 자아 존중감을 가진 아동은 긍정적으로 행동하고 책임감이 있으며, 어떤 좌절에도 잘 견디어 내고 자신의 행동 을 자랑스러워하고 만족하게 된다(Winggins \& Winggins, 1992). 이에 반해 낮은 자아 존중감 을 가진 아동은 적절한 감정 표현이 이루어지지 못하여서 대인관계의 어려움을 갖고, 아동 들은 학교생활에 적응이 어렵게 되어 낮은 사회성으로 타인과의 상호작용이 어렵게 된다 (차미성, 2005). 자아에 대한 긍정적 관점을 확립하지 못하면 자신의 가치와 성공 감을 경험 하지 못하고 다른 사람의 가치도 인식하지 못해 반사회적 효과가 나타날 것이다(안지숙, 2008).

이러한 아동의 심리적 갈등과 문제행동을 해결하기 위한 치료방법에는 모래놀이치료, 미 술치료, 놀이치료와 그 밖에 다양한 매체를 사용하는 치료요법들이 있다. 이중 모래놀이치 료는 자연물인 모래와 물 그리고 3차원적인 표현으로 일상생활에서 볼 수 있는 소품을 사 용하여 모래상자에 자유롭게 배열하면서 무의식의 심상을 표현하는 방법이다. 아동기는 언 어로 자신의 생각과 감정을 표현하기가 매우 어려운 시기이기 때문에 내면의 문제를 언어 로 표현하여 의식화하는데 어려움이 있다. 그러나 모래놀이치료는 언어가 아닌 일상생활에 서 자주 접할 수 있는 친숙한 소품과 놀이로써 자연스럽게 무의식의 심상을 표현하도록 도 와 아동에게 매우 적합한 매체라고 할 수 있다. 또한 모래놀이치료는 치료자와 함께 안정 되고 보호된 공간에서 충분히 이완되면서 자유롭게 무의식의 심상을 표현함으로써 아동의 퇴행을 돕고 자기치유력을 활성화시켜 적극적으로 개성화과정을 이루도록 돕는다.

모래놀이치료는 Lowenfeld의 세계기법(world technique)에 Jung의 분석 심리학을 적용하여, 모래놀이(sandplay)라 명명한 Kalff에 의해 시작되었다. Kalff는 모래놀이치료를 통해 내담자가 자신의 무의식과 대면하여 자기 치유력을 발휘 하고 정상적인 자아발달과정으로 나아가는 개성화과정으로 보았다. 개성화과정에서 무의식과 대면은 모래와 물 그리고 소품을 배열하 는 모래놀이를 통해 자연스럽게 이루어진다. 모래놀이실은 내담자가 정서적. 물리적으로 외 부세계로 부터 보호 받고 공감 받는 공간이며 내담자 자신의 부정적인 내면으로부터 내담 자를 안전하게 보호하는 공간이다(장미경, 2017). 모래를 만지는 손은 정신과 신체를 연결시 키는 역할을 한다(Ammann, 2001). 모래와 물을 사용하는 모래놀이치료에서 소품은 아동의 단어이고 놀이는 아동의 언어이다(Landreth, 2002).

또한, 모래놀이는 비언어적인 심리. 정서 치료기법 중의 하나로 언어로 나타낼 수없는 생 각을 모래상자와 소품을 통해 작품이라는 이미지로 나타내는 동시에 의식화 하는 것이 가 능하다(채영순, 2000). 언어능력이 빈약한 아동에게 효과적이며 모래놀이는 원형세계와 개인 내적세계 둘 다를 포함하고, 아동이 외부의 일상 현실과 접촉하도록 허용하는 도구라고 보 
았다. 상징적 놀이는 의식과 무의식 사이의 의사소통을 만들어 준다고 가정하였다(Boik \& Goodwin, 2000). 모래놀이의 기본 치유가정은 인간정신에 타고난 치유력이 있다고 본다는 것이다(장미경, 2017).

Jung은 개성화 과정은 개인의 심리발달사로 전반부와 후반부로 나누어진다고 하였다 (Neumann, 2004). 개성화과정의 전반부인 아동기는 신체적, 인지적 발달의 시기이며 부모로 부터 자립하여 독립을 향해 나아가는 자아발달의 시기이다(Jung, 2006g). 자아가 부모로부터 자립, 독립하는 과정에서 부모와 갈등이 시작된다. 또한 자아 내면에서 도덕성의 발달과 함 께 자아와 그림자의 분열로 갈등이 발생하는 과정에서 문제행동이 나타나기 시작한다(Jung, 2006h). 아동의 자아는 이러한 갈등과정을 거치면서 자기(Self)와 교류하며 발달하게 된다. 그 러나 자아발달과정에서 아동이 경험하는 모와 분리, 상실, 방임, 학대 등의 외상과 지식 위 주의 현대교육은 강압적으로 일방성을 띄며 목표를 향해 나아가게 한다. 그 결과 아동의 자아는 자기(Self)에서 멀어지고(Jung, 2006b) 의식과 무의식의 불균형을 초래하여 자아의 발 달은 정체되고 문제행동이 나타난다.

본 사례의 아동은 불안정 애착으로 인해 모로부터 분리되지 못하여 자율적이고 독립적인 학령기 자아발달이 지연되었다. 내담아동은 자신의 감정과 의사를 자발적으로 표현하지 못 하고 모에게 의존적인 성향이 강하였으며 이로 인해 타인과의 긍정적인 의사소통의 경험도 제한되어졌다. 모래놀이를 통해 애착외상의 경험을 치유하고 지연된 아동의 자아발달과 성 장을 증진하고자 한다.

\section{ㅍ. 사례개요}

\section{1. 내담 아동의 행동관찰 및 의뢰경위}

내담아동은 초등학교 5학년 여아로 체격은 보통아동과 같았으나 마른편이고 치료자를 만 났을 당시 수줍은 듯 눈을 마주하지 못하였다. 모가 아동에게 선생님께 인사를 하라고 하 자 아동은 말없이 고개를 숙여 인사를 하였다. 그러한 아동의 모습이 자신감이 없고 낮선 장소나 사람을 어려워하는 것 같아보였다. 모는 아동이 학교생활에서 또래에게 자신의 의 사를 잘 표현하지 못하고 또래와 어울리지 못하는 것 같아서 아이가 어떤 문제를 가지고 있는지 염려가 된다고 하였으며 아동이 고학년임에도 불구하고 모가 동행하지 않으면 혼자 등하교하는 것에 어려움이 있다고 하였다. 밖에서는 자기표현을 못하는 아동이 모에게는 말대꾸를 하며 모의 말을 잘 따르지 않아 모와 갈등이 많다고 하였으며 사회성이 부족하고 자율적인 기본 생활습관도 잘 수행 되지 않아 모는 아동의 모든 생활에 관여를 할 수 밖에 
Journal of Symbols \& Sandplay Therapy, Vol.11 No.2.

없다고 하였다. 아동의 모는 아동이 감정표현이 미흡하고 자신의 의사를 또래나 담임선생 님에게 잘 표현하지 못하며 모에게도 자신의 의사를 표현 하지 못하고 짜증과 울음으로 자 신의 감정을 충동적으로 처리하고 있다고 하였다. 이러한 의사소통 방법으로 인하여 내담 아동은 또래관계에서 자신의 의견을 표현하지 못하는 어려움을 격고 있으며 부정적인 정서 의 형태로 짜증을 많이 내고 모와 갈등이 심하게 되어서 염려가 된다고 하였다. 아동은 고 학년이 되면서 학습을 따라가기 힘들고 특히 수학은 많이 어렵다고 하였으며 모와 헤어져 혼자 학교에 가는 것이 어렵고 성격이 강한 아이들과는 관계하는 것이 어렵다고 하였으며 모는 이러한 아동의 문제를 해결하고 싶어서 상담을 의뢰 하게 되었다고 하였다.

\section{2. 발달사 및 가족사}

모가 아동을 임신 했을 때 아동의 모는 아동의 조모 병간호를 하느라 심리적으로 육체적 으로 많은 어려움이 있었다. 아동은 14 개월에 걷기를 시작 하였으며 언어와 자조행동, 신체 발육이 늦는 편이었다. 아동은 돌 무렵에 상해로 2주 정도 입원 한 적이 있었으며 잘 울고 겁이 많았고 다른 사람에게 안기거나 다가가지 않았다. 3세까지도 모가 먹여 주어야 밥을 먹었으며 편식을 하는 편이었으며 엄마와 떨어지려고 하지 않았다. 또한 옷 벗기나 옷 입 는 것이 보통의 아이들 보다 늦었으며 스스로 하지 않으려고 하여 모가 다 해 주었다. 두 살터울인 둘째 양육으로 인해 3 세 때 어린이집을 보냈는데 처음에는 적응을 잘 하였으나 모가 몸이 아파 이모 집에서 3 일 이모가 돌봐준 후 부터는 어린이집에 가지 않으려고 하였 다. 이시기에 아동은 모에게 자신의 필요를 간단한 언어로 표현 하기는 하였으나 타인과는 전혀 소통하지 않았다. 6세 때 유치원 에서는 뒷마무리를 잘 하지 못하고 아동이 수행해야 하는 것들을 을 잘 하지 못하였다. 또한 의사소통이 잘 되지 않아 또래와도 어울리지 못하 므로 원 생활에서 어려움이 있었다. 현재는 소극적인 성향임에도 불구하고 모에게는 말대 꾸가 심하고 지시에 순응적이지 않다고 보고하였다. 두 살 터울 여동생과 자주 싸우고 동 생에게 화를 잘 내기는 하나 집밖에서는 의사표현을 잘 하지 못하고 언어 이해력이 늦은 편이라 타인의 상황에 대한 이해력이 부족하다고 한다. 가정 내에서는 부모나 동생에게 공 격적이고 짜증도 잘 내는 경향이 있으며, 학교에서 또래와의 관계에서는 자기표현이 강한 아이들과는 잘 놀지 못하고 회피적인 태도를 보인다고 한다. 또한 외부 어른과의 관계에서 심하게 불편해하고 부끄러움도 많아 대인관계의 어려움이 많다고 한다.

내담아동의 모는 4남매 중 막내로 어린 시절 부모의 갈등과 별거로 인해 형제들과 함게 어린 시절을 보내지 못하고 본인만 부와 함께 어린 시절을 보냈으며 어려운 가정형편으로 이른 나이에 취직을 하게 되었다. 그 후 24 세에 결혼을 하였으나 남편의 외도와 폭력으로 이혼을 하였으며 부부 사이에 자녀는 없었다. 이혼 후 지인의 소개로 지금의 남편을 만나 
재혼 하였으나 결혼 생활이 만족스럽지 않다고 하였다. 재혼한 남편과 사이에 태어난 첫 자녀인 내담아동에게 기대는 많았으나 남편과의 갈등과 경제적 어려움으로 아동을 안정되 게 양육하지 못하였다고 한다. 지금도 아동이 독립적이지 않고 모에게 지나치게 의존적이 라서 불만이지만 아동에 대한 불안감으로 인해 과잉하게 개입하고 잔소리를 많이 하게 되 었다고 한다. 또한 아동의 학업에 대한 기대가 높아 사교육을 많이 시켰으나 아동은 따라 가기가 힘들었고 이로 인해 자신감이 더 저하 된 것 같다고 한다. 이에 비해 두 살 터울의 여동생은 똑똑한 편이어서 부모의 인정을 많이 받고 언니를 잘 도와주기도 하나 자주 싸운 다. 아동의 부는 6남매 중 막내로 태어났으나 형제들과의 관계는 소원 한 편이라고 한다. 조그만 개인사업체를 운영하는 부는 경제적인 부분에 과도하게 예민하며, 남을 많이 의식 하고 가부장적이어서 내담아동에게 따듯한 정서적 소통보다는 객관적으로 판단한 것을 냉 정하게 표현하는 편이라고 하였다.

\section{3. 치료적 접근}

아동의 모는 자신이 배우지 못한 것을 아동을 통해 성취 하고자 하는 옥구가 있어서 어 려운 형편에도 사교육을 시키며 아동에 대한 기대를 가졌던 것으로 보인다. 또한 어린 시 절 다른 형제들과 헤어져 부와 생활함으로 인해 모성의 다스한 경험을 하지 못했을 것이 다. 아동의 모는 자신의 어린 시절 정서적으로 돌봄 받지 못한 환경에서 자란 것의 보상으 로 좋은 엄마가 되고 싶었고 아동에게 잘 하려고 했던 것이 오히려 아동을 지나치게 통제 하고 아동에게 과도한 기대를 가지고 능력에 맞지 않는 학습을 시키며 아동의 자율성과 독 립을 방해 하였다. 아동은 정서적 돌봄이 필요한 영아기에 정서적 수용의 경험을 하지 못 함으로 자신감이 없고 자신의 의사 표현을 적절한 방법으로 하지 못하고 짜증과 울음으로 표현 하였으며 또래 관계도 잘 하지 못하게 되었다.

에리히 노이만(Neumann)은 원초적 관계의 혼란으로 인해 발달과정의 어려움이 생기는 이 유를 개인적인 어머니의 실패와 그로 인한 부정적 모성원형 에너지의 배열로 보았다 (장미 경,2017). 따라서 치료에서 이루어져야 할 것은 생애 전반부에서 문제가 된 원초적 단계를 재구성 하고 손상된 자기-자아축을 재생산할 수 있는 환경을 만들어 주는 것이다

이러한 아동기의 자아 발달의 결핍이나 고착을 해결하기 위해 모래놀이치료를 적용하였 다. Kalff(1980; 2003)는 결핍으로 인해 고착된 자아가 모래놀이치료를 통해 새로운 심리를 재구성하여 정상적인 자아의 발달단계로 나아가게 된다고 하였다. 즉 자아발달을 정상적으 로 이루지 못한 아동이 모래놀이치료를 통해 건강한 자아발달로 회복하는 것으로 고유한 아동자신의 모습을 찾아 가는 과정을 통해 내담아동이 가족, 또래 및 다른 사람과의 사회 적 관계를 향상 시키며 자신의 의사 표현을 짜증이나 말하지 않는 것으로 하는 것이 아니 
Journal of Symbols \& Sandplay Therapy, Vol.11 No.2.

라 적절히 자신의 감정이나 의사를 표현 할 수 있도록 하였다. 내담아동이 외부 세상과의 관계에서 보여지는 소극적이고 회피적인 태도는 모의 양육태도와 가정 내의 환경과 관련이 깊으며 모-자녀 관계의 신뢰를 회복하고 안전한 애착의 경험이 아동으로 하여금 지연된 자 아 발달을 회복함으로 자신의 의사표현을 긍정적으로 하고 또래관계의 원만함을 갖도록 하 였다.

\section{III. 모래놀이 치료 과정}

본 내담자는 2019년 4월부터 9월까지 6개월간 개별모래놀이치료를 진행 하였다. 총 17회 기를 진행 하는 동안 아동은 매 회기마다 모래놀이를 실시하였으며 모의 요청으로 종결된 사례이다. 모는 경제적인 여건과 아동이 또래관계가 전보다 많이 좋아지고 자기표현도 잘 하여서 더 이상 놀이를 하지 않겠다는 의사를 15 회기에 표현하였다. 아동에게 종결을 예고 하고 2 회기를 더 실시하여 17 회기에 종결하였으며 본 사례에는 17 개의 모래사진을 담고 있다.

모래놀이 초기에 아동은 자아의 혼돈과 혼란을 물과 모래를 섞으며 놀이를 하는 모습으 로 나타내었으며 많은 물을 사용했다. 모래놀이 중기에 아동은 무의식의 대면인 갈등을 다 양한 투쟁과 사건에 의한 죽음으로 표현하고 모래를 짓이기고 섞으며 놀이 하였으며 동물 소품과 음식 피규어를 사용했다. 후기는 자아와 자기의 건설단계와 집단에 적응의 단계로 동물들로 표현된 시골마을에서 곰 가족과 그의 친구들이 농사를 짓고 오리는 먹을게 없어 서 떡을 만들고 있는 장면을 만들었다. 농사를 짓고 음식을 만드는 것은 새로운 자아의 재 탄생과 양육의 표현이다. 칼프(1989)는 모래놀이치료를 융의 분석심리학과 동양사상, 로웬펠 트의 기법 등 3가지 근원을 바탕으로 칼프 만의 기법을 발전시켜 "sandplay"라는 새로운 이 름을 붙이게 되었다. 칼프의 모래놀이치료 단계는 Neumann(1973)의 심리적 발달 과정에 영 향을 받았다. Neumann의 심리발달 이론은 5 단계로 분류하였는데 1 단계는 혼돈, 2 단계는 동 - 식물의 단계, 3 단계는 투쟁의 단계로 구분하였으며, 4단계는 자아와 자기 축의 단계, 5 단계는 집단에 적응하는 단계이다(turner, 2014). 이와는 달리 칼프는 3 단계로 구분되며 구체 적으로 각 단계를 살펴보면 다음과 같다.

제 1단계는 혼돈의 단계로 동·식물 단계(The Animal-Vegetative Phase)이다. 아동의 정서 적 혼란과 혼돈을 반영하는 작품으로, 대개 첫 작품이나 초기의 작품에 나타난다. 아동의 경우는 어떠한 테마를 가지고 만든다기보다는 오히려 혼돈의 상태처럼 보이는데, 이는 정 신없이 상자 전체에 가득 채우듯이 흐름은 알 수 없으나 대체적으로 동물과 식물을 많이 사용하는 것을 흔히 볼 수 있다(turner,2014). 혼돈의 단계는 정신의 모든 측면을 한꺼번에 
나타내는 매우 복잡하거나 또는 황폐한 느낌을 주는 건조하고 생명력 없는 장면을 드러내 기도 한다. 또한 도덕이나 규범, 규칙 때문에 억압되어 있는 무의식적인 본능이 활성화되는 표현으로 정글, 공룡나라 많은 물을 사용한다. Neumann(1973)은 이러한 혼돈의 모습이 아직 분화되지 않는 혼란스러운 자아의 초기 모습을 드러내는 것이라 고하였고, 이 단계를 초기 어머니-아동의 경험으로 마치 신생아가 자신과 어머니를 구별하지 못하는 것 같은 단계라 고 하였다. 동물과 식물이 나타나는 단계에 있어서는 아동이 어머니로부터 분리되기 시작 하는 발달 단계로 보았고 이것을 친선단계(rapprochement stage)라고 부르는데 대상 영속성 (object constancy)이 발달되는 시기라 할 수 있다. 이 때 어떤 유형의 동물을 선택하느냐는 매우 중요한 의미를 지닌다. 유아의 발달단계에 따라 원시적인 동물을 선택할 수도 있고, 아니면 친근감을 주는 동물을 택할 수도 있다. 일반적으로 말이나 소보다 공룡을 선택하는 것이 보다 깊은 공격성을 설명해 주고 있다고 말한다(이정숙·고인숙, 2002). 제 2단계 투쟁 의 단계(The Fighting Phase)는 혼돈과 동-식물의 단계가 지나면 대극을 이루면서 투쟁이라 는 형태로 전쟁 장면이나 파괴적인 장면들이 많이 나타난다. 예를 들면 적군과 아군의 싸 움이라든지 색깔이 다른 공룡들의 싸움이라든지 상자의 왼편과 오른편의 사선을 그어서 투 쟁을 벌이든지, 만화에서 등장하는 인물 또는 동물 중에서도 맹수가 약한 동물을 잡으려 하는 등의 투쟁을 벌인다(김보애, 2005). 이 단계에서는 땅이 폭발하거나 총에 맞는 등의 장 면들이 많이 나타나며, 치료의 중반기로 갈수록 전투가 강렬해지고 조직화되며, 일반적인 파괴가 아니라 균형 있는 투쟁이 나타난다. 또한 영웅이 등장하여 힘을 행사하는 장면이 꾸며진다. 이때 여자 아동들은 소품들을 이용하여 공상을 그들의 본능과 연결하여 표현하 는 것을 볼 수 있다. 즉, 자기와 동일시되는 인형을 가두는 등의 행동이 보이기도 한다. 3 단계 집단에의 적응의 단계(The Phase of Adaptation to the Collective)는 충분한 투쟁의 단계를 거치면 적응의 단계로 통합해 가는 모래상자를 볼 수 있다. 아동은 자신의 내면세계에 몰 입을 한 후 통합과정에서는 집단에의 적응의 단계를 보여준다(turner, 2014). 이시기에서는 정상적인 일상사의 반영을 보여 주는데 Neumann은 이 시기를 아동이 외부세계와 관계를 가질 준비를 하는 단계로 생각하였다. 또한 이 시기는 학교 가기, 또래관계 등 모든 것은 어머니와의 초기 양육 관계에서 벗어나 외부로 향하는 세계관을 보여준다. 이 시기에는 질 서가 회복되어 자연과 사람 사이의 균형이 잡히며 생활에 리듬이 생긴다. 동물들은 적절한 곳에서 살게 되고 마을과 도시가 균형을 이루며, 추수를 나타내는 작품들이 만들어지기도 한다. 여자 아동들은 사람과 지역사회를 적절히 연결하고 친밀감을 주는 마을을 꾸민다. 이 단계의 끝으로 가면 여자아동들은 매우 여성적인 상징들을 보여 준다. 모래상자놀이의 말 기에는 완전함과 전체성을 상징하는 원이나 네모 등의 이미지가 나타나며 이는 모래놀이치 료를 통한 본능적인 힘의 통합을 의미한다고 볼 수 있다(Kalff, 1989) 이러한 세 단계의 과 정은 자아의 발달 과정인 동시에 자아와 자기와의 관계를 개선하는 과정이고, 사회성의 발 
Journal of Symbols \& Sandplay Therapy, Vol.11 No.2.

달을 시작하는 과정이며 부모를 포함하여 사람들과의 관계를 개선하는 과정을 나타내는 것 이다(이숙 외, 2002). 본 연구에서는 칼프의 접근방법이 전 세계적으로 가장 널리 사용되고 있다는 점에 기초하여 칼프의 모래놀이치료 3 단계를 사용하였다.

아동의 상자에서는 동식물단계의 혼란스러움을 많은 물의 사용과 동물로 표현되었으며 투쟁단계로 대립과 투쟁, 부자, 가난함, 음식으로 나타났다. 마지막단계인 일상의 적응단계 에서는 비록 동물들로 표현되었지만 농사를 짓고 떡을 만드는 다양한 형태로 일을 하는 마 을을 나타내었다.

\section{1. 혼돈과 동식물단계}

\section{1) 1 회기}

말을 잘 하지 않는다는 모의 보고와는 다르게 기다려주면 정서를 표현하였다. 소극적인 면이 있기는 하나 안전하다고 느껴지면 자신을 표현하고 소통하고자하는 의지가 내담아동 에게 존재한다는 것으로 보여 졌다. 왼쪽 부분의 비어져 있는 모래상자의 모습은 마치 아 동이 모에게 정서적 지지를 받지 못하는 답답함, 적막감, 고립감같이 느껴졌다. 아동이 가 장 먼저 눈에 띠게 가져다 놓은 것은 침대다. 침대가 잠과 관련된 쉼, 무기력, 무의식을 상 징 한다면 이 아동은 심리적으로 아주 심하게 지쳐 있을 것이다. 그런 이유는 아동이 이해 받지 못하고 있다고 생각하기 때문인 것으로 보여 진다. 그래서 아동은 엄마에게 말해봤자 소용이 없어서 짜증과 말하지 않는 것으로 반응 했을 수도 있다고 여겨졌다. 그러나 그 상 태로 그대로 있으면 안 된다는 것을 아동의 무의식은 알고 있는 것 같다. 그 증거로서 침 대 옆에 소통을 의미하는 전화기가 있다(Ackroyd, 1993). 또한 흥미롭게 그 옆에는 장롱이 있다.

장롱은 서양에서는 비밀을 상징 하지만 우리문화에서는 비밀을 의미 하는 경우가 전혀 없다. 영화 나니아 연대기에 보면 아이가 장롱을 통해 무의식의 세계로 들어간다. 마치 이 장롱은 나니아 연대기의 장롱을 연상 시킨다(https://namu.wiki/w/). 영화의 내용에서 그 장롱 은 광장히 무섭게 느껴지기 때문에 처음에는 용기가 필요했다. 아동은 어쩌면 자신의 무기 력을 극복하고 건강해 지기 위해서, 또래들과 관계 맺고, 자기의 의사를 분명하게 나타내 보이기 위해서는 컴컴하고 무서운 장롱에 들어가는 용기를 내야 할지도 모르겠다. 치료과 정은 아마 그 장롱 안에 들어가서 치유를 받고 성장하는 것을 의미할 가능성이 높다. 그런 데 또 한 가지 흥미로운 것은 그 옆에 거울이 있는데, 거울은 자기를 비추어 보고 자기의 정체성을 보고 자기를 객관적으로 비추어서 타인과 분리됨을 경험하고 지각 하는 것의 상 징이다(Cooper, 1978). 이 아동은 지금 거울을 가져다 놓았다. 내담아동 가까이에 자리 잡은 토끼가 거울 앞에 있다. 토끼가 혼자 살고 있는 곳이라고 아동은 말했다. 혼자 살고 있다는 
것이라고 말 한 것의 의미는 두 가지가 있는데 하나는 혼자 산다는 것은 심리적으로 고립 되고 사회적으로 또래관계에서 고립되어 있고 광장히 외롭다는 것을 의미 할 수 있고 또 한 가지는 우리나라에서 토끼는 달나라 계수나무 아래서 방아를 찧는다. 이것은 아동이 무 언가 도달해야 하고 성취해야 함을 의미 한다고 볼 수 있다. 또한 토끼는 아메리카 동부삼 림지대의 인디언들 사이에서는 장난꾸러기(TRICKSTER)로 통한다(Cooper, 1978). 내담아동은 토끼와 같이 자유롭고 장난기 있는 놀이를 통해 퇴행의 옥구를 충족하고 싶어 하는 것으로 보여 진다. 토끼 발 앞에 줄로 연결되어 있는 작은 장난감 오리가 있다. 오리는 하늘과 땅, 정신과 육체를 연결 하는 연결의 상징인데 오리발에 끈이 달린 것으로 보아 연결이 더 강 조된 것으로 보인다. 또한 아동은 내면의 어떤 에너지와 분열되어 있기 때문에 지금 무기 력 한데 그 에너지와 다시 연결될 필요가 있는 것은 아닐까 하는 생각이 들기도 한다. 또, 한 가지는 어렸을 때 욕조에 넣고 놀이 하는 장난감 오리로 어린 시절의 퇴행을 의미 할 수도 있다. 그래서 장롱으로 들어가는 것은 성장 하고 독립하는 것을 의미 한다면 오리는 퇴행 하는 상태로 이 사이에서 갈등하는 상태는 아닐까 하는 생각이 든다. 또 한 가지는 자기의사를 뚜렷하게 분명하고 당당하게 표현해서 관철 하는 독립적인 태도보다는 울고 징 징대고 짜증내고 수동적으로 자기를 표현 하는 퇴행을 의미 할 수도 있다. 퇴행과 독립 사 이에서 아동은 갈등 하는 것은 아닐까? 그래서 이 모래상자는 바로 이 아동이 두려움을 극 복하고 퇴행에서 벗어나서 그 장롱 안으로 들어가 두려움과 맞서야 하는 여정에 들어가야 하는 것은 아닐까 생각 된다. 아이상태로의 지금의 모습과 앞으로 나아가 진정한 자아를 찾아야 하는 퇴행과 독립의 혼돈된 상태로 보여 진다.

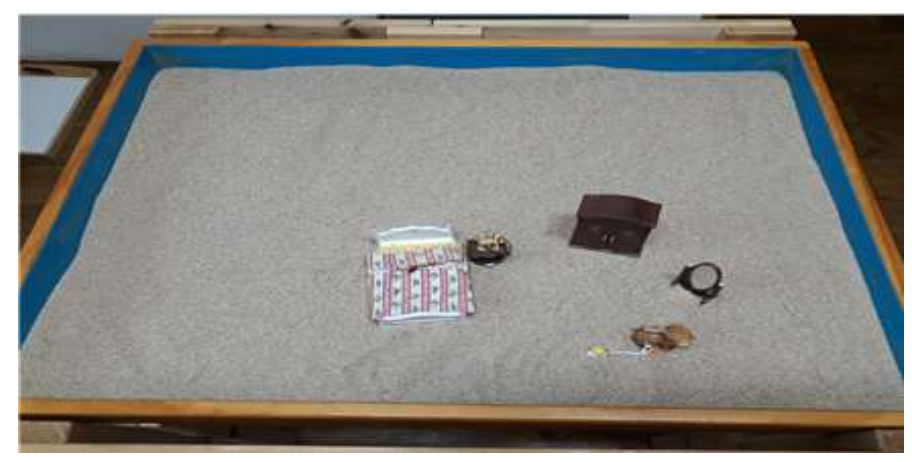

Sand picture \#1

\section{2) 2회기}

아동은 모래놀이 장을 여기저기 살핀 후 피규어를 가져와 말없이 자리에 앉은 후 모래상 자 위에 침대를 제일 먼저 가져 다 놓은 후 장롱, 피아노, 토끼, 오소리를 놓은 후 침대 좌 
Journal of Symbols \& Sandplay Therapy, Vol.11 No.2.

측에 세면대를 가져다 놓았다. 그 후 모래를 만지기도 하고 양 옆으로 휘저으며 모래를 가 지고 놀았다. "여기는 다람쥐네 집.. 다람쥐는 혼자" 라고 말하였다. 혼자 살고 싶은 이유는, “엄마잔소리가 싫어서” 라고 말할 때 치료자를 쳐다보며 처음으로 웃는 모습을 보였다. 아 동이 피규어를 고르는 시간이 오래 걸린 것은 자기스스로 어떤 결정을 하는 것에 어려움을 갖는 성격일 수도 있을 것 같다.

북유럽에서는 우주 수 이그드라실(YGGDRASIL)에 사는 다람쥐 '라타토스크는 비, 물, 눈 을 가져오며, 또한 원한과 악극의 상징이기도 하고 이그라드실에 살면서 독수리와 뱀을 싸 움 붙였다(Cooper, 1978). 세계수 위그드라실 이야기에서는 다람쥐가 나무 정상의 독수리와 뿌리에 있는 독뱀 니드오그 사이에서 괴로운 메시지를 나르면서 나무의 몸통의 아래위를 오르락 내리락 뛰어 다닌다(Turner, 2014). 이 신화에서 말하는 자기형상으로 현시화 되기 위해서 끊임없는 투쟁을 견뎌야함을 아동은 모래놀이를 통해, 독수리와 뱀을 싸우게 한 다 람쥐처럼 자신의 내면의 무의식과 현실의 모성에게 의존하는 자신의 상태에 대한 혼란의 자각을 시작한 것 일 수도 있다고 보여 진다. 이것은 내담 아동이 진정한 나로서 살고 싶 은 나와, 내담아동의 모에 의해 길들여진 자신과의 갈등이 시작되었음을 상징 하는 것 일 수도 있다고 본다.

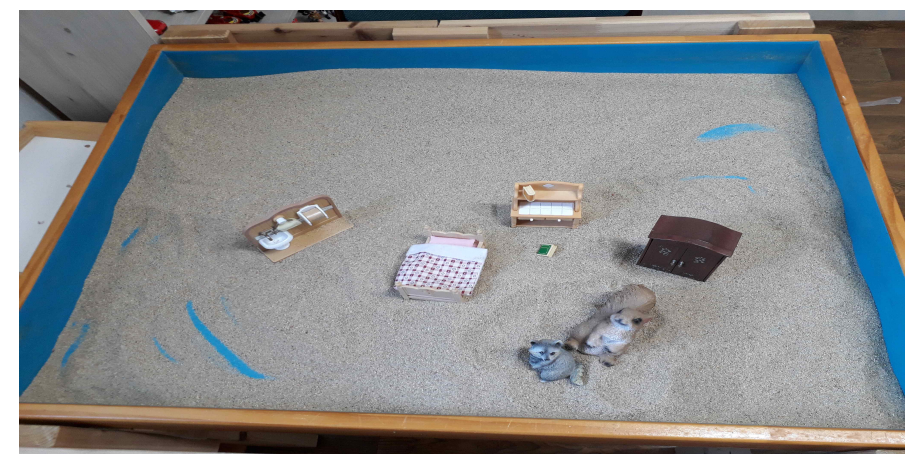

Sand picture \#2

\section{3) 3회기}

아동은 치료자를 쳐다보고 아주 작은 소리로 “물” 이라고 말하였다. 처음으로 치료자에 게 자신의 필요를 언어로 표현 하였다. 아동은 처음으로 물을 사용 하였다. 아동은 물과 모 래를 섞으며 아무 말 없이 오랫동안 놀이를 하였다. 이 동작은 자신의 내면세계로 깊이 하 강하는 행위로 보여 지며 물을 다시 부으며 피규어가 물에 잠기지 않도록 옮겨 가며 물과 모래를 계속 섞으며 놀이를 하는 모습은 마치 새로운 세상을 만들고자 하는 창조자의 모습 과도 같아 보였다. 물은 형태가 없는 카오스상태의 상징이다. Jung(2006h)은 집단무의식을 
어둠과 여명의 상태로 주체와 객체의 구별이 불가능하며 하나의 동일한 것으로 융합된 카 오스 상태라고 말했다. 물은 이러한 집단무의식처럼 한 주체로서 구별이 어려운 미분화상 태로 여러 물질과 융합될 수 있는 가능성을 상징한다. Eliade(1952)도 물이 일체의 ‘존재 가 능성의 원천’이며 '저장고'라고 말했다. 이와 같이 물과 카오스는 생명과 성장의 가능성을 보유하고 있지만 아직은 형태가 없는 혼돈된 상태이다. 물은 무의식을 상징한다(Cooper, 1978). 아동은 자신의 무의식으로 하강 하여 혼돈된 상태, 미분화된 상태의 자아를 모래놀 이를 통해 돌아볼 준비를 한 것으로 보여진다.

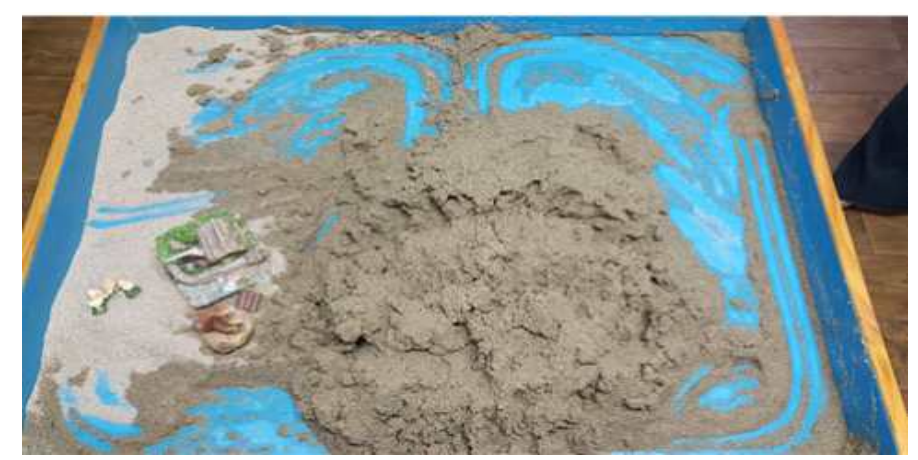

Sand picture \#3

\section{4) 4회기}

내담 아동은 물을 흥건하게 부은 후 아주 오랫동안 물과 모래를 섞으며 놀이를 하였다. 모래를 모았다가, 헤치고 다시 모으고 구멍을 판 후 그 구멍으로 물을 부은 후 다시 짓이 기는 행동을 계속 반복 하였다. 놀이 하는 동안은 모래상자에서 고개를 푹 숙이고 한참동 안 모래를 섞은 후 모래상자 왼쪽 위 모서리에 $\mathrm{tv}$ 와 쇼파를 놓은 후 쇼파 위에 오소리를 놓았다. “잔소리 하는 엄마가 없어서 좋아요" 라고 말하였으며 오소리를 가리키며 “목옥, 진훍탕에서 놀아서” 라고 말 하였다. 또한 “망했어요." 라고 집을 가리키며 말하였다. 치료 자가 느낌을 물으니 “좋아요. 썩은 바다. 굶어 죽었어요. 너구리가 썩어서 썩은 바다가." 라 고 말하였다.

모래놀이에서 물은 모래를 침식시키고 진창이 되게 하며 경계를 없앤다(Turner, 2005). 젖 은 모래를 사용하는 것은 정서적인 부분을 해결하고자 하는 자아의 의도이다(Ammann, 2001: Grubbs, 1995). 물은 무의식을 상징하는 바다로 표현되기도 한다. 특히 학대받은 아동 이 정상아동에 비해서 많은 물을 사용하여 홍수를 나타내거나 진창의 젖은 모래를 사용한 다(Grubbs, 1995; Mitchell, 2012). 바다는 썩은 바다가 되고 너구리가 굶어죽었다는 의미는 내 담아동이 그동안 모성으로 받은 부정적 정서를 분노로 표출한 것처럼 보여 진다. 망한 집, 
Journal of Symbols \& Sandplay Therapy, Vol.11 No.2.

썪은 물, 굶어죽은 너구리 등은 아동의 무의식의 죽음을 상징적으로 말한 것 같다. 죽음 후 새로운 탄생이 있다. 노아시대 홍수로 죄악으로 인해 혼돈된 세상이 멸망하고 새로운 세계 가 만들어진 것처럼 아동의 내면세계에 죽어야할 것들은 죽고 새로운 자신의 것을 스스로 만들어 나갈 것을 기대해본다(창7장17-24).

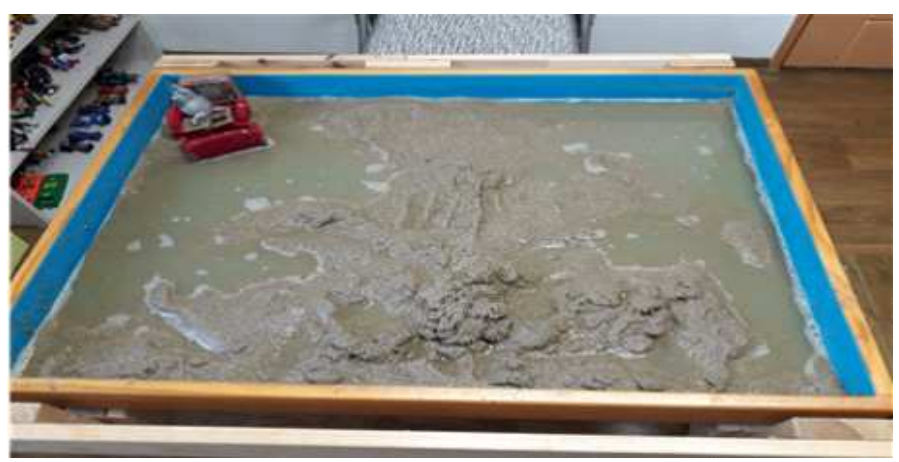

Sand picture \#4

5) 5회기

아동은 “집이 망해서 이사를 왔어요. 엄마 아빠는 없어." 라고 말한 후 치료자를 바라보 며 살짝 미소 지었다.

아동은 모래상자에 여러번 물을 쏟아 부었는데 물을 부을 때 아동은 조심하지 않고 붓는 모습이 통쾌해 보였다. 많은 양의 물은 홍수, 쓰나미, 진창속의 죽음을 표현한다. 이는 심리 학적으로 모든 기능의 정지이며 하나의 세계를 해체하는 것으로, 근원지와의 만남을 유도 한다(박행자, 2012). 초기에 나타난 홍수는 모든 에너지가 잠재적으로 정체되어 있는 카오스 상태로 초기 외상(Trauma)을 경험한 아동들에게 많이 나타나는 심한 외상(Trauma)의 표현이

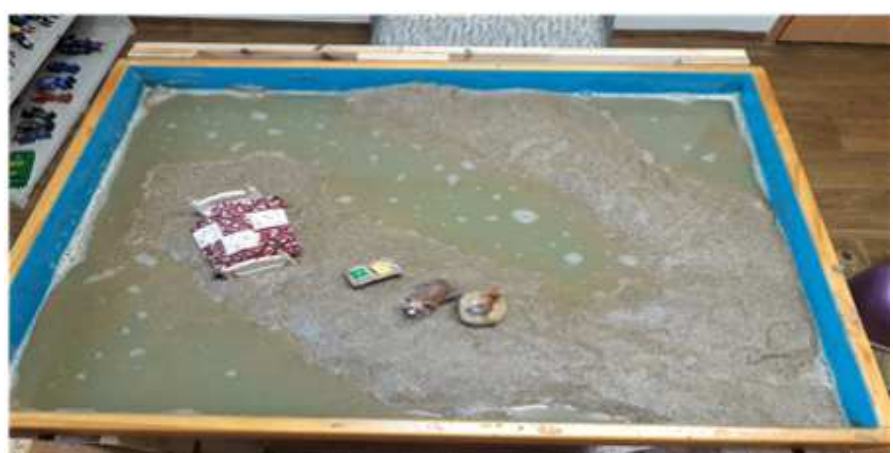

Sand picture \#5 
며 중기에 나타난 홍수는 무의식과 만남으로써 죽음에서 재탄생의 전조현상이라고 할 수 있다(Turner, 2005). 홍수는 내면의 감정의 분출을 상징 할 수도 있다. 압도 당 하면 안 되니 까 무의식에 담가졌다 건져내는 과정을 해내고 있다. 내담아동이 말한 망한 상태는 어떤 의미에서는 부모로부터 받은 억압된 자율성과 독립, 정서적 돌봄을 받지 못한 것을 의미할 수도 있다고 볼 수 있으며 집단무의식의 부정적 모성 원형의 상징 일 수도 있다고 본다.

\section{2. 투쟁단계}

\section{6) 6회기}

한참동안 말없이 모래를 짓이기던 아동은 위에서 아래로 U자 모양을 만든다. 그리고 다 시 한 번 물을 붓는다. 아동은 치료자에게 송아지를 가리키며 “예네들이 집이 마음에 안 들어서 갯벌로 이사 갔어. 집에 먹을 것이 없어서 갯벌에서 먹을 것을 찾고 있어요.” 라고 말 하였다. 갯벌은 갯가, 즉 바닷가의 넓은 벌판이란 뜻이다. 이곳은 바닷가의 평편하고 물 의 흐름이 완만한 곳에 물속의 휽알갱이들(퇴적물)이 내려앉아 만들어진다. 갯벌 안에서는 수많은 생명들이 쉴 새 없이 먹고 이동하며 치열한 삶을 꾸려가고 있다. 아동이 집에 먹을 것이 없어서 갯벌로 이사를 가는 행위는 먹을 것이 없는, 정서적으로 메마른 이곳을 떠나 자신에게 필요한 양분을 찾아 떠나는 아동의 독립성과 자아의 발달을 의미한다. 아동은 집 이 마음에 들지 않아서 갯벌로 이사를 가는 능동적인 행동을 한다. 자신의 삶속의 필요를 적극적으로 찾아가는 이 모습은 모에게 억압되어 자신의 의사를 긍정적으로 말하지 못하고 짜증을 내던 것을 언어로 표현 할 수 있는 힘이 생긴 것이다. 모의 보고에 따르면 아동은 또래친구에게 “왜 나만 하라고 하는데!, 잘난 척 하지 마" 등의 말을 할 수 수 있었다고 한 을 했다고 한다. 또한 잠잘 때 엄마를 떨어져서 자지 못했는데 친구 집에 가서도 잠을 자 고 올 수 있었다고 한다. 4 는 여성적 에너지, 여성의 수라고 볼 수 있는데 모래사진의 송아

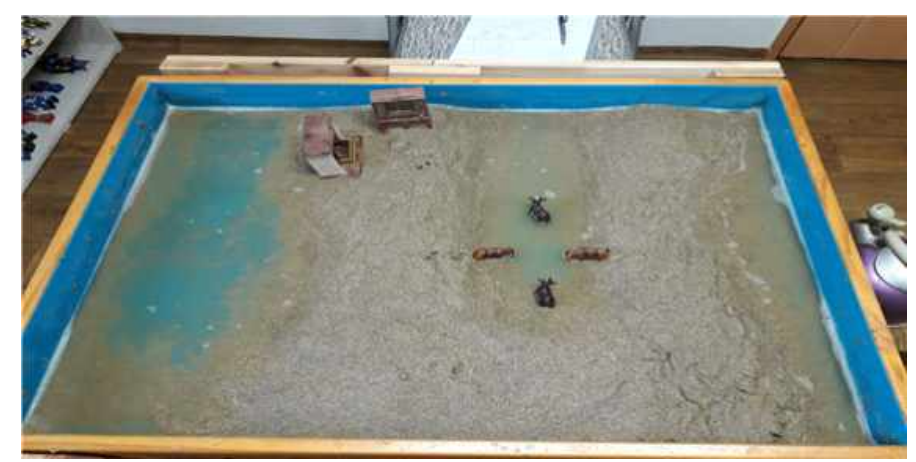

Sand picture \#6 
Journal of Symbols \& Sandplay Therapy, Vol.11 No.2.

지 사위는 아동에게 의식의 발달을 이루어가며 자신의 여성성의 발달도 함께 이루어감을 의미할 수도 있다고 생각 된다(Eastwood, 2006).

\section{7) 7 회기}

“홍수가 나서 물이 많아 져서 갯벌 위에 다시 집을 지었어요. 엄마 오리는 잔소리가 많 아서 없는게 좋아요.” 라고 말하며 이를 드러내며 웃음 지었다. 그리고 엄마 오리를 가리키 며 “엄마 오리는 빵 먹으려고 해요. 그런데 홍수가 나서 물이 너무 많으면 양동이로 퍼내 면 되요.”라고 말 하였다.

상자의 사용 항목에서 젖은 모래를 사용하는 것은 정서적인 부분을 해결하고자 하는 자 아의 의도이다(Ammann, 2001: Grubbs, 1995). 물은 무의식을 상징하는 바다로 표현되기도 한 다. 특히 학대받은 아동이 정상아동에 비해서 많은 물을 사용하여 홍수를 나타내거나 진창 의 젖은 모래를 사용한다(Grubbs, 1995; Mitchell, 2012). 아동은 모래를 뒤섞으며 자신의 내면 에 있는 억압된 감정을 모래에 쏟아 붓는 것 같아 보였다. 말없이 오랜 시간 동안 모래놀 이에 몰입한 아동의 모습은 자신의 잃어버린 자율성을 찾는 듯하였다.

오리는 하늘과 물의 중개자이다(Cooper, 1978). 아동에게 오리의 상징은 이고와 셀프의 연 결을 의미할 수도 있겠으나 빵을 먹고 있는 오리와 아기오리는 아직 돌봄을 받아야 함을 나타낸다고 볼 수 있다.

모래사진의 U자 모양은 이러한 양육의 컨테인을 의미 할 수 있으나 아직은 안전하게 보 호된 상태는 아닌 것처럼 보인다. “물이 너무 많으면 양동이로 퍼내면 된다”는 아동의 표현 에서 두 가지로 볼 수 있는데 한 가지는 모의 과잉된 억압의 상태로 볼 수 있으며 양동이 로 퍼내는 것의 의미는 자신의 잃어버린 자율성을 찾는 것과 독립을 할 수 있다는 긍정성 이 엿보인다. 모의 보고에 의하면 이때 아동은 혼자 잘 수 없었는데 자기 방을 따로 갖고 싶다고 하였다고 한다. 아동기는 학교에서 동성의 또래 관계 형성에 관심 갖게 되면서 자

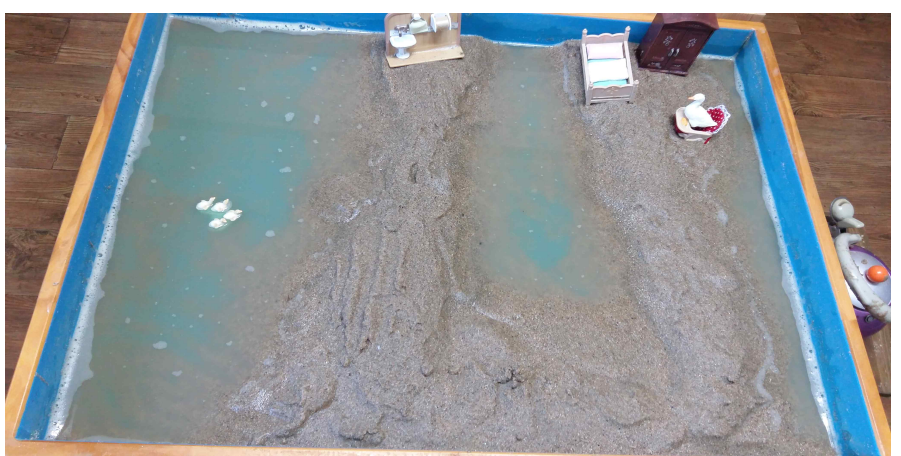

Sand picture \#7 
아를 강화하는 시기이다. 이 시기에 긍정적인 발달은 사회적으로 수용되는 생활과 지적인 활동에 에너지를 활용하면서 자아의 근면성을 기르고 사회에 적응하는 능력을 갖게 되는 시기이다(최경숙, 2006). 이 회기에서 아동은 친구가 방을 혼자 쓴다고 하며 나도 내방을 갖 고 싶다고 말했다고 한다. 아동이 자신만의 공간을 갖고 싶다는 의미는 모로부터 분리 하 는 독립의 욕구를 나타낸 것으로 보여 지며 모와의 관계보다 또래 관계 안에서 또래들만이 느끼고 공유하는 것에 관심을 갖고 있다는 것은 아동의 의식이 발달 되어감을 의미할 수도 있다고 보여진다.

\section{8) 8회기}

“물이 차서 이사를 갔고 오리와 펭귄은 친구예요. 왼쪽은 모래섬이고 오른쪽은 연결된 뚝 이예요” 라고 말 하며 치료자를 쳐다본 후 말을 멈췄다. 아동은 한참동안 무슨 생각을 하는 듯한 표정으로 아래를 보고 U자 언덕을 쓰다듬으며 "내가 다른 친구를 도와준 적은 없고 다른 친구는 나를 도와줘요" 라고 말 하더니 약간 어두운 표정으로 “공부가, 원래 따 라가기가 힘들었는데 엄마는 공부를 잘 해야 한다고 해요.” 라고 말 하더니 모래를 만지며 "새집이 생겨서 좋은데 모래 느낌이 가칠까칠 해요." 하며 살짝 웃는다.

모래놀이치료에서 물의 사용은 자아의 의도적인 행위로 무의식에 직접적이고 세밀하게 참여하는 것이다. 즉, 물의 접촉은 무의식의 접촉에 대한 신뢰를 수반하고 물이 흡수되는 유동성은 자아를 자기에게로 안내하여 새로운 힘을 가져온다(Turner, 2005). 모래놀이치료에 서 물은 모래를 침식시키고 진창이 되게 하며 경계를 없앤다(Turner, 2005). 모래놀이 중기 에 나타난 홍수는 무의식과 만남으로써 죽음에서 재탄생의 전조현상이라고 할 수 있다. 모 래상자에서 적절한 양의 물이 사용되는 경우, 물은 재탄생으로 생명수, 우물, 식수, 강, 바 다 그리고 세례 등으로 표현된다. 이는 심리학적으로 미지의 것으로 나아가는 자아의 의도 적인 행동이다. 이는 양분된 자아가 자기의 영역으로 움직이는 것이다(Turner, 2005). 아동은 이제 자신의 자아발달을 모래놀이경험을 통해 해 나가고 있는 것이다.

펭귄은 무리를 지어 생활한다. 특히 새끼가 성장하면 새끼들만의 집단을 만드는 특성이 있다. 팽귄의 등장은 새끼가 성장하면 새끼들만의 집단을 만들 듯이 아동 또한 또래집단에 서의 적응을 나타낸다고 볼 수 있다. 이것은 사회성의 시작을 의미하며 모권에서 부권으로 의 이동을 기대해 볼 수 있다. 이번회기에서 아동의 모는 아동이 또래친구에게 "나대지 마!” 라는 표현을 하였다 며 이제는 자신의 감정을 언어로 하는 것이 신기하다고 하였다. U 자 모양에서 둥근 모양으로 변해가는 것이 보여 지는데 이것은 아동 내면의 중심화가 되어 가는 것을 의미 한다고 볼 수 있으며 아동의 자아발달이 이루어져 가는 것 의 전조 현상으 로 보여진다. 


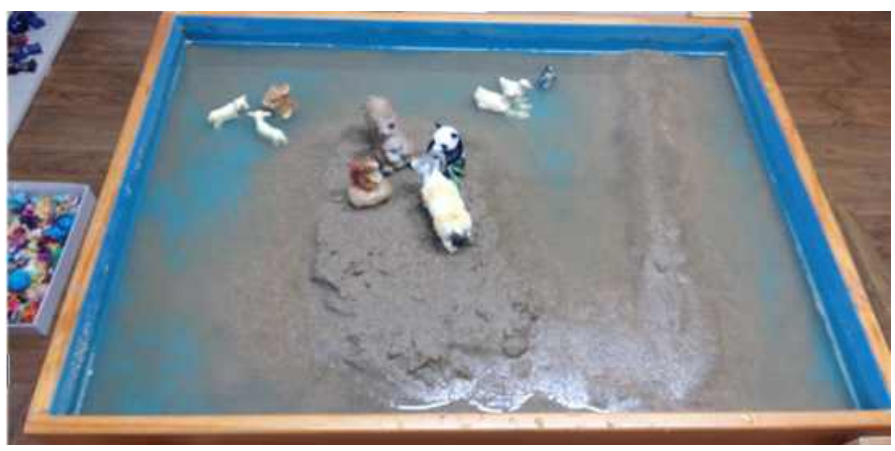

Sand picture \#8

\section{9) 9회기}

"아빠오리는 열심히 일 하고. 언니 오리는 공부해요. 엄마오리가 자는 것을 보고 있어요. 아기오리는 침대에서 자요." 언니 오리는 공부를 열심히 하는데 자기 자신은 공부 하는 것 이 어렵고 힘들다고 말 하였다. 공부하는 오리의 모습이 자신과 같이 느껴진 것 같다. 아동 이 어려워하는 과목은 수학과 과학인데 5학년 올라와서 너무 어려워서 따라가기 힘들다고 하였다. 아기오리가 잠자는 모습을 어미오리가 지켜보고 아빠오리도 침대 옆에서 일을 하 는 모습, 그 옆에 공부하는 언니오리의 모습에서 아동은 부모의 충분한 돌봄을 경험하기를 원 하는 것으로 보여 진다. 위의 젖은 모래와 아래의 파란 바닥이 드러나 보이는 것은 물 과 땅이 위 아래로 나뉜 것이기도 하며 이것은 아동의 모와의 단일 체 에서 분리 개별화가 일어나고 있음을 의미 할 수도 있다. 여전히 아래 바닥에는 물이 차 있지만 물의 양이 줄 어들었음을 볼 수 있다. 모래놀이치료에서 물은 모래를 침식시키고 진창이 되게 하며 경계 를 없앤다(Barbara, 2005). 모래상자에서 적절한 양의 물이 사용되는 경우, 물은 재탄생으로 생명수, 우물, 식수, 강, 바다 그리고 세례 등으로 표현된다. 아동은 이제 점진적으로 자아 가 자기의 영역으로 움직일 준비가 되어 있음을 보여 주는 것으로 보여진다.

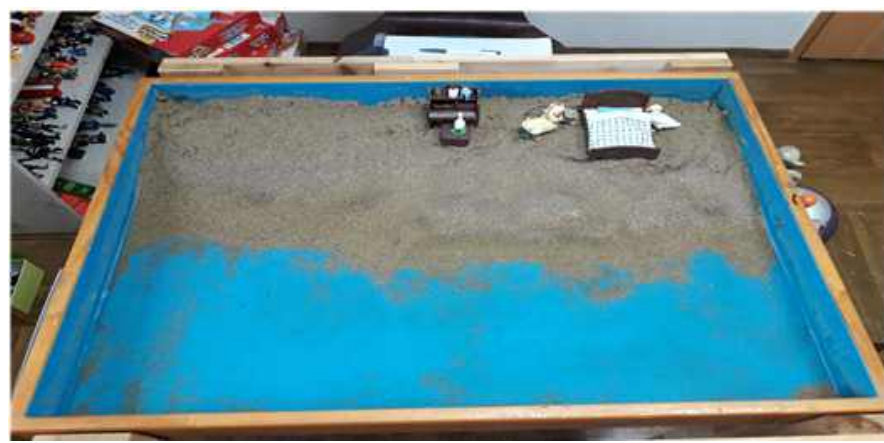

Sand picture \#9 
모래상자에서 위는 하늘, 의식, 남성적인 힘을 나타낸다. 아래는 무의식, 지하세계, 여성 적 힘을 나타내는데 아동의 모래상자는 위의 의식영역에 오리가족을 표현 하였다. 이것은 의식세계에서 안정된 가족관계안에서 돌봄이 있을 때 정서적 안정감을 느낄 수 있고 이러 한 돌봄이 있을 때 아동은 자신의 발달을 충분히 이루어 나갈 수 있음을 의미한다고 보여 진다(Turner, 2005).

\section{0) 10 회기}

아동은 토끼가 혼자 있고 싶어서 무인도에 왔는데 친구에게 전화 하고 있는 것이고 나중 에는 파도 때문에 무너져서 슬프다고 말 하였다.

원숭이는 뺀뻔스러움, 몰염치, 호기심, 나쁜장난, 비천한 본능을 상징 한다(Cooper, 1978). 식탁위에 앉아 있는 원숭이, 그 옆의 화장대 거울에 비치는 원숭이는 아동의 무의식에 있 는 본성을 바라보고 직면 해가는 과정일수 있음을 보여준다. 아동의 모는 아동이 요즘 친 구에 대한 이야기를 엄마에게 하고 자신의 일을 조금씩 자발적으로 해 나가고 친구를 맞춰 주며 자신을 조절 하는 것 같다고 보고 하였다. 모래놀이에서 중심화가 시작된 것으로 보 여 지고 이러한 모의 보고는 아동의 자아 발달이 진행 되어 감을 의미 한다고 볼 수 있다. 원모양의 안쪽에 보여 지는 계단 모양은 아동의 내면의 의식화가 이루어지는 단계를 보여 준다고 할 수 있다. 중심화가 된다는 것은 더 높은 차원을 향하고 의식적인 자각을 접근 하도록 도와준다는 것이다(Turner, 2005). 아동의 자기배열이 되어가는 과정을 보여준다고 할 수 있다.

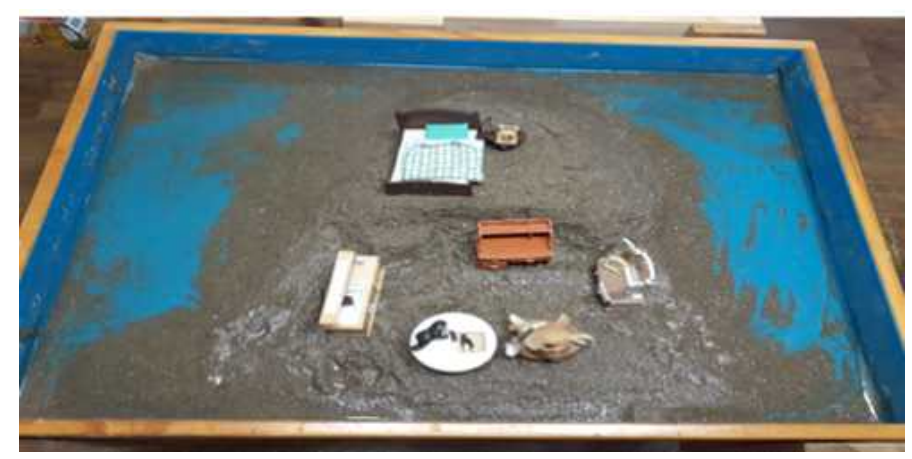

Sand picture \#10

\section{1) 11 회기}

아동은 “친구 집에 놀러왔어요. 이곳은 섬 이예요. 몽키가 섬에 사는 이유는 물놀이를 하 려고..그리고 바나나가 많아요. 부모는 이곳에 없고 서울에 살고 있어요. 전화해서 다람쥐 
Journal of Symbols \& Sandplay Therapy, Vol.11 No.2.

친구를 놀러 오라고 헸어요. 나라면 이곳에 혼자 있으면 무서울 것 같아요. 상자안의 꽃은 엄마 주려고 해요."라고 말하며 치료자를 쳐다보며 “5학년 때부터 수학이 힘들어요. 그림그 리기 하는 걸 좋아 해요."라고 말 하였다.

모래상자에 중심화가 선명하게 이루어져 가고 있다. Eliade(1990)는 신성함이 나타나는 곳 은 어디든지 중심이라고 하였다. 이는 모래놀이가 신성함이 구현되는 공간적 위치로 작용 하며 내담아동이 모래와 물을 혼합하여 상자 중심에 정성을 들여 모으는 행위는 마치 신성 한 의식 같았으며 중심을 향해 집중하는 내담아동의 정신의 움직임으로 느껴졌다.

아직은 모래사진이 중심으로 집중된 완벽한 사분위의 만다라를 형성하고 있지는 않지 만 머지않아 통합적 의식의 출현을 예고한다 하겠다. 부정적 모성원형을 극복하고 의식과 무의식을 분리를 통해 완전한 전체성을 가지는 것은 이상향이라고도 할 수 있다. 물의 출 현과 혼합은 모의 어두운 그림자를 벗어나 자신의 무의식으로 하강을 두려워하지 않게 된 내담아동의 긍정적 발달에 에너지로 보여 진다. 또한 세면대와 샤워기의 출현으로 보 아 자신을 씻기는 정화의 과정으로 보여진다. 꽃은 중심으로 바깥으로 움직여 나오는 에 너지의 발현으로 상자안의 꽃은 아직은 드러나지 않지만 잠재된 Self의 출현으로 볼 수 있다(David, 1993). 계단은 상승, 초월, 새로운 존재론적 수준으로의 이행을 뜻한다. 원모양 안의 계단은 의식성 발달의 형상으로 아동의 자아가 발달되며 의식화가 되어 감을 다시 한 번 보여준다.

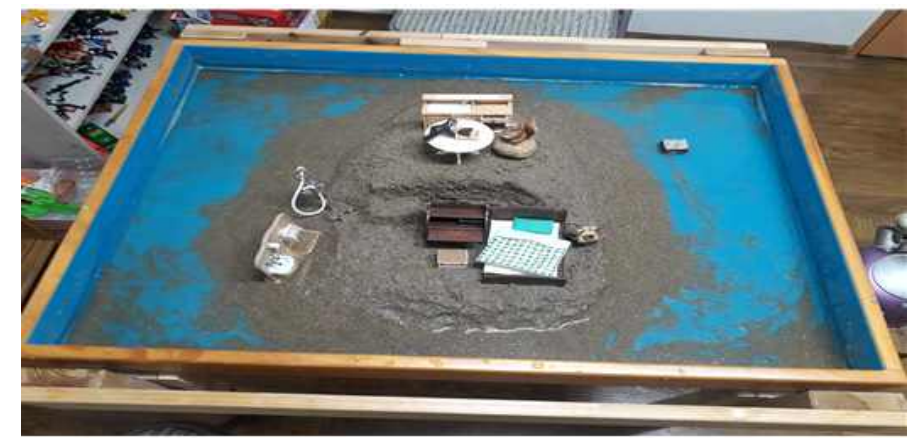

Sand picture \#11

\section{2) 12 회기}

"왼쪽은 처음에는 거지였는데 열심히 일을 해서 부자가 되었고 오른쪽은 처음에는 부자 였는데 돈을 마구 써서 거지가 되었어요. 여기는 무인도예요. 왼쪽은 좋고 오른쪽은 슬퍼 요. 나는 진아 랑 잘 놀아요. 나랑 맞는 것도 있고 안 맞는 것도 있어요. 진아 는 뛰어 노 는걸 좋아하고 나는 조용하게 앉아서 노는 게 좋아요." 
무의식의 영역인 모래상자의 왼쪽에 넓은 육지가 드러내고 있으며 그 곳에서 관계의 옥 구를 상징하는 원탁의 테이블과 소파가 놓여있다. 아마도 무의식으로의 깊은 관계가 시작 됨을 의미하는 것 같다. 본 회기의 모래상자에는 왼쪽 아래의 육지와 오른쪽 아래의 작은 육지가 유아기에 모-자녀 관계에 관한 자기표현인 듯하다. 어머니와의 안전한 심리적 분리 를 위해 Self의 양육을 받고 있는 것으로 여겨지며 지금까지 기능적으로 작용하지 못한 ego 가 건강한 ego로의 발달을 예고한다. Self의 양육을 받지 못한 내담아동의 ego는 팽창되거나 소외된 공허한 상태이며 기능적으로 작용하지 못 하였다(Neumann, 2004).

아동의 말에서 부자, 가난함, 맞는 친구, 안 맞는 친구 등의 표현은 부정적인 모성원형과 긍정적 모성원형의 대극적인 모습이 출현한 것으로 보여 진다. 이것은 모에 대한 양가감정 과 모와의 심리적 분리가 되어 감을 보여준다고 볼 수 있다. 아동이 친구와 맞는 것도 있 고 안 맞는 것도 있다는 말에서 아동은 자신을 통찰 한 것으로 보여 지며 이러한 것이 통 합될 때 타인과의 관계 안에서 자신을 어떻게 표현해야 하는가를 알 수 있을 것 이라고 본 다. 오븐은 변환의 상징이다. 오븐은 컨데인 할 수 있으며 그 안에서 음식을 익히는 과정의 변환이 일어난다. 이러한 오븐의 상징은 아동이 부자, 가난함, 맞는 친구, 안 맞는 친구 등 의 대극적인 부분을 오븐 안에서 음식이 익어지며 변환되듯이 자신의 것으로 통합되어져야 한다.

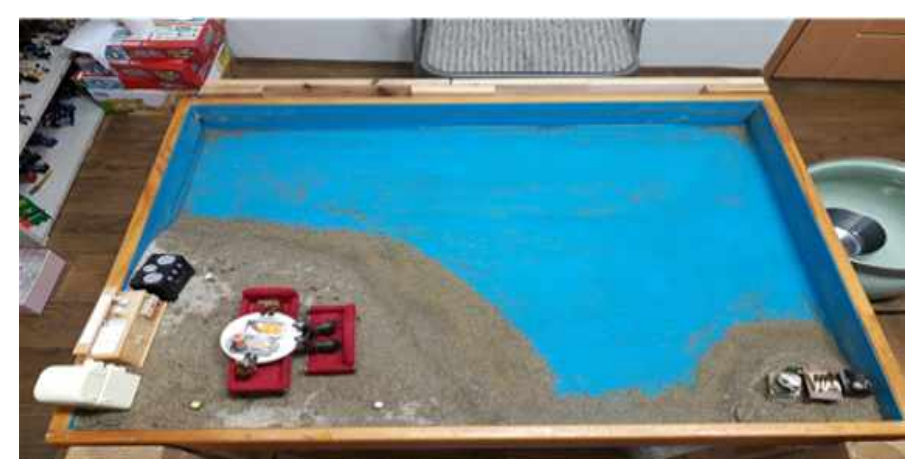

Sand picture \#12

\section{3) 13 회기}

"이곳 아이들은 원래 부자였어요. 이곳은 섬 이예요. 바다에서 놀다가 파도 때문에 이곳 에 오게 되었어요. 이 집에는 이 가족만 살아요. 오른쪽은 무인도예요. 원래는 예네들도 이 섬에 왔는데 예들이 자기네가 먼저 왔다고 쫓아 버렸어요. 오른쪽 아이들은 친구예요."

아동이 이번 회기에 만든 세계는 무인도, 섬이다. 섬은 격리와 고독의 장소인 동시에 혼 돈의 바다로부터의 안전한 피난처이다(Cooper, 1978). 상반되는 두 가지 상징을 내포하고 있 
Journal of Symbols \& Sandplay Therapy, Vol.11 No.2.

는 섬이라는 지형은 내담아동에게 계속 머물고 싶은 파라다이스일수도 있으며 새로운 세상 으로의 발달을 저해하는 속박의 땅이기도 하다. 이는 우로보로스로 상징화된 모-자녀 단일 체에서 개별 분리화를 통해 어머니의 세계와의 점진적인 분리되고 아버지의 세계로의 변환 을 예고한다. 내담아동이 느끼는 개인적인 모와 관련된 무의식의 내용들도 양가적이거나 혼란스러울 수도 있을 듯하다. 이는 자신을 과잉보호하여 자발적이고 독립적인 자아 발달 을 저해하는 부정적 모성원형의 극복과도 관련되어져있을 것으로 여겨진다.

고양이는 여성적인 신비함을 간직하고 긍정적이고 창조적인 측면을 나타낸다(Ackroyd, 1993). 또한 인내, 욕망, 자유를 뜻한다(Cooper, 1978). 음식은 평화와 불화의 해소의 상징이 며 생명력, 친교를 상징한다(David, 1993). 아동은 모로부터 억압된 여성성을 회복함으로 또 래관계가 잘 이룰 수 있는 힘이 길러지고 자신의 감정을 긍정적으로 표현 할 수 있는 힘이 길러질 것으로 기대 된다.

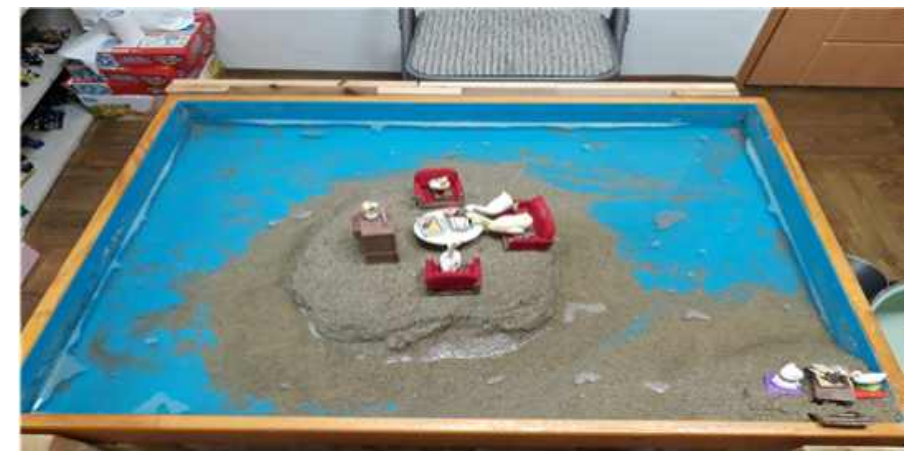

Sand picture \#13

\section{3. 일상으로의 적응단계}

14) 14 회기

"아이들만 있고 엄마아빠는 다른 곳에 있어요. 이곳은 무인도예요.

오른쪽도 아이들만 있어요. 엄마아빠는 일하러 갔어요."

아동은 이제 자신의 자아가 형성되어지고 모로부터 독립을 하는 단계에 이른 것 같아보 인다. 무인도에 아이들만 있고 부모는 일 하러 갔다는 아동의 말과 풍성하게 차려진 음식, 이러한 것은 아동에게 충분한 양육과 돌봄이 자기 스스로 되어 질 수 있음을 의미 할 수도 있다고 본다. 


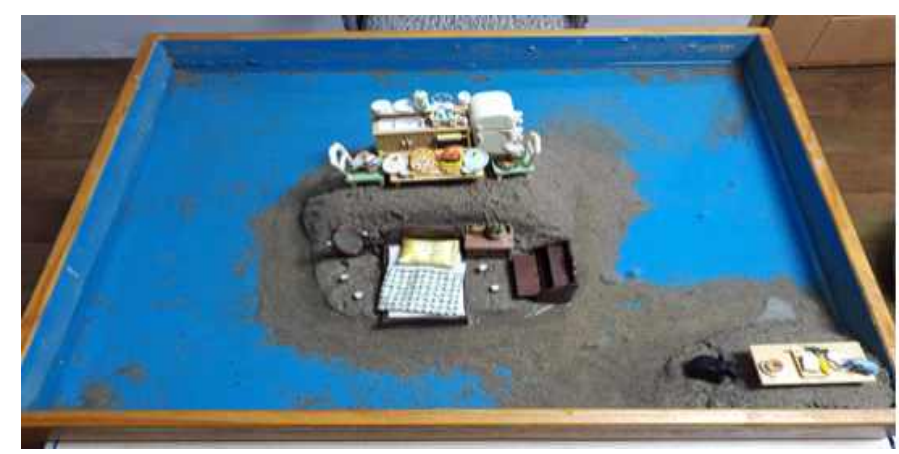

Sand picture \#14

15) 15 회기

"이곳은 공원 이예요. 친구들과 함께 먹고 있는 중이예요.

오리 생일 이예요. 친구들과 생일 파티를 하고 있어요."

모래상자의 중앙 부분은 내담아동의 사이키의 중요한 핵심이며 Self의 중심이라고도 할 수 있다. 중심에서 일어나는 중심화 행위는 자기 원형과 관련되기 때문에 모래놀이에서는 매우 중요하다(Turner, 2005). 중앙부분의 모래언덕을 내담아동이 자신의 무의식과 관계하고 나아가 세상과의 관계를 펼쳐주는 신성한 곳으로 여겨진다. 신성한 공간은 신성한 시간으 로 진입을 촉진한다. Eliade(1990)는 신성함이 나타나는 곳은 어디든지 중심이라고 하였다. 이는 모래놀이가 신성함이 구현되는 공간적 위치로 작용하며 내담아동이 모래상자 중심으 로 모래를 모으는 행위는 마치 중심을 향해 집중하는 내담아동의 정신의 움직임으로 느껴 졌다.

오리는 하늘과 땅을 연결 한다. 아동은 ego와 Seif의 연결이 되어가는 모습으로 볼 수 있 다. 생일 파티는 탄생을 축하하는 것이다. 친구와 함께 생일축하를 하는 장면은 또래관계 안에서 즐거운 경험을 하는 것으로 보이며 한편으로는 새로운 탄생을 의미하기도 한다. 아

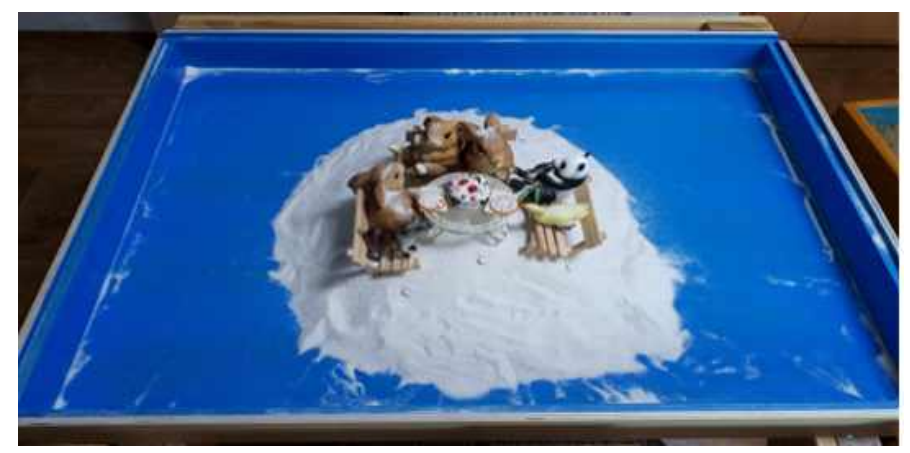

Sand picture \#15 
Journal of Symbols \& Sandplay Therapy, Vol.11 No.2.

동은 진정한 자기로 탄생되어짐을 축하하는 의식을 치룬다고 할 수도 있다. 사춘기에 접어 든 아동은 부모에게서 무관심하기를 원한다. 또래끼리 어울려 다름을 받아들이는 과정을 경험해야 한다. 그러한 과정에서 자신의 정체성을 찾아가고 자신과 다른 타인을 받아들일 수 있게 된다.

\section{6) 16 회기}

“친구가 돈을 빌려갔는데 안줘서 혼내주고 싶어요. 엄마가 학교에 데려다줘요. 아직 혼자 버스타고 다니지는 못해요. 버스타면 다른 곳에 내려 줄까봐... 엄마는 잔소리 할 때가 싫고 잔소리 안 하면 좋아요. 모래상자의 이 아이들은 공원에서 만나 집까지 같이 왔어요. 이 아 이들은 서로 맞는 친구들이예요 서로 안 맞는 친구가 있어요. 나는 조용한 놀이가 좋은데 아이들은 술래잡기 놀이를 좋아해요. 나는 하기 싫어도 해요. 아이들이 기분 나빠하고 왕 따 시킬까봐... 그런데 막상 하면 재미있어요.(미소) 1 학년, 2 학년 때 왕 따 당한 적이 있어 요. 머리에 이가 있다고 친구 엄마가 놀지 말라고 해서 못 놀았어요. 나는 아파트에 살고 싶은데 강아지 때문에 주택에 살아야 해요." 아동은 친구관계에서 하고 싶지 않지만 왕따 당하지 않기 위해 함께 하다 보니 즐거움을 경험한다. 또한 자신이 살고 싶은 곳은 또래와 함께 관계하기 쉬운 아파트이지만 강아지를 위해서 주택에 살아야 함을 받아들인다.

아동의 모래상자 중앙에 기린이 앉아 있다. 기린은 조망을 멀리 볼 수 있음을 상징한다 (Cooper, 1978). 그것은 어떤 상황을 객관적으로 볼 수 있는 인지력이 있음을 말한다. 내담자 가 세상을 바라보는 조망이 생겼다는 것은 내담자의 정서적 변화와 발달을 의미한다. 목이 길거나 관이 높은 동물은 신성성 즉 영(spirit) 또는 내면세계와 관계하는 상징을 지니고 있 다. 모래상자를 꾸미고 내담아동은 자신이 느끼고 있는 가족에 대한 보고를 진솔하게 내어 놓기 시작하였다. 자기감정이나 특히 자신의 가족과 관련된 이야기나 느낌 보고에 회피적 이고 비밀스럽던 내담아동의 사이키에 변화가 생긴 것으로 보여진다. 또한 또래 관계의 상

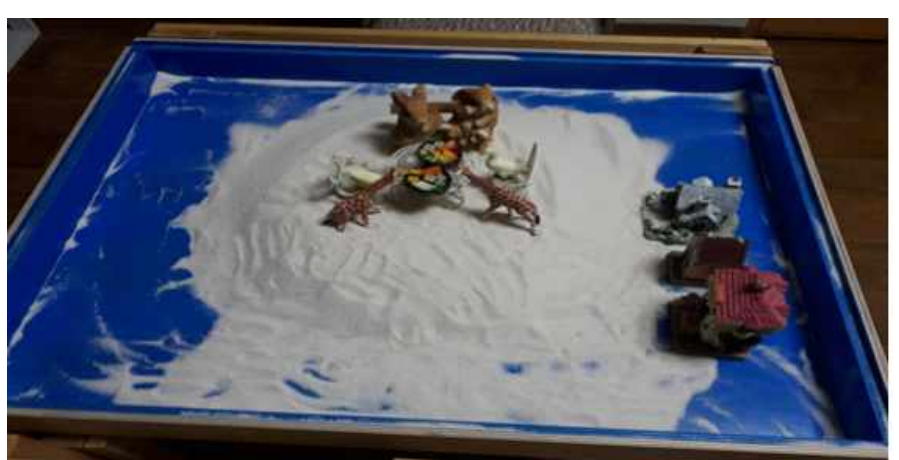

Sand picture \#16 
처에 대한 진솔한 자기보고는 자기 인식 능력이 발달되었음을 의미하며 이와 함께 외부세 계를 객관적으로 바라보는 시야가 생겼다는 것을 암시한다.

내담아동이 외부세계 즉 $\mathrm{eg}_{0}$ 의 영역과 내부세계 즉 자신의 무의식의 영역이 모래놀이를 통해 소통하고 있는 것으로 보여 진다. 아동은 모의 과잉 돌봄과 억압으로 자라지 못했던 어린 아이에서 기린이 조망을 멀리 볼 수 있는 것처럼 객관적으로 자신을 바라볼 수 있는 인지력 이 길러진 것으로 볼 수 있다. 하지만 오른쪽에 있는 집은 여전히 양육과 자양분이 필요함을 나타내고 있다고 볼 수 있다.

\section{7) 17 회기}

“시골마을이에요. 곰 가족과 그의 친구들이 농사를 짓고 있어요. 오리는 먹을게 없어서 떡을 만들고 있어요. 느낌이 좋아요."

코끼리의 상징적 표현은 일반생활과 상업 분야에서 그 동물이 맡은 중요한 역할로부터 유래한다. 전통적으로 군주와 대군들이 그 등에 높이 앉아 타고 다녔던 수송 수단이었던 코끼리는 죽음에 대한 승리 노령의 지혜와 위엄을 뜻했다. 아동은 그동안 모성에게 의존했 던 부분에서 스스로 해나갈 수 있는 힘을 생겨남을 상징 할 수도 있다.

탑은 남근을 상징하는 것 일수 있다. 탑은 여성에게는 아니무스를 상징한다. 아동은 관계 에 있어서 자신의 의사를 표현하고 행동함에 있어서 자신감을 갖고 생활 할 수 있는 힘이 생겨남을 의미 할 수도 있다.

도시는 자기의 상징이다. 도시로 들어가는 것은 무의식을 탐구하고 거기에서 일어나고 있는 것과 친숙하게 되려는 의향, 또는 필요성을 상징한다(Ackroyd, 1993). 아동은 실생활에 적응할 준비가 되어있음을 보여주고 있다.

남성적 형태를 한 곰은 남아메리카 원주민들과 중국인들에게는 용감성과 힘을 상징했다 (David, 1993). 곰은 아동에게 이고 발달의 상징으로 보여 지는데 이제 자신의 결정을 스스 로 할 수 있는 힘이 길러진 듯하다. 집들을 배치하여 마을이 형상화되고 농사를 지음으로 경작을 수확을 예고한다. 내담아동의 세계에도 과제의 성취나 자존감의 획득과 같은 일들 이 펼쳐질 것으로 보여진다.

마지막 회기에 곰 4 마리, 집 16 채의 숫자의 출현한 것은 내담아동의 통합의 에너지를 강 하게 상징한다. 4 는 달의 4 주기, 사계절, 의식의 4 가지 요소를 상징하며 의식화의 행위를 통해 경험하는 네 가지 기본 양상이며 무엇인가 새로운 것이 시작되는 경계를 의미한다. 또한 16 은 $4 \times 4$ 이므로 4 의 특성과 관련이 있으며 의식의 네 가지 측면의 완전히 분화된 실현의 상징이다(Abt, T, 2005/2007). 모와의 원초적 단일체로부터 분화하여 새로운 자아 의 식성을 탄생하여 다음 발달의 과업을 무사히 수행하게 될 것이다. 이처럼 상징은 내담아동 이 이제는 자신의 정체성을 찾아가는 여정을 시작했다고 알려주는 듯하다. 


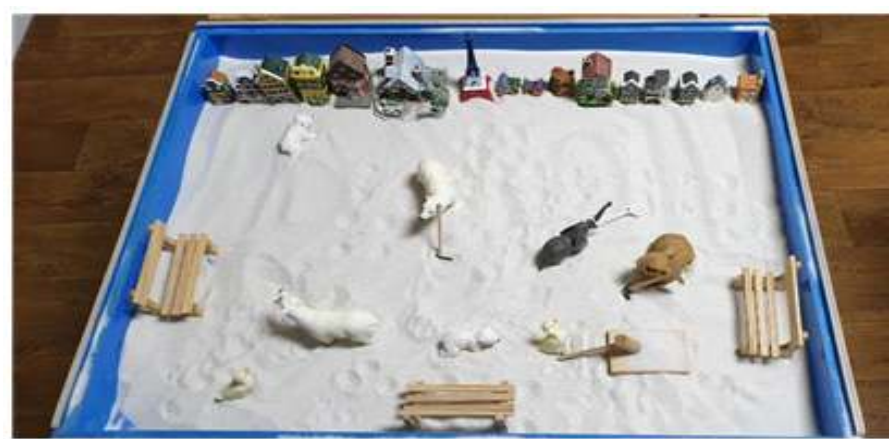

Sand picture \#17

\section{$\mathrm{IV}$. 결 론}

본 내담자는 총 17 회기의 모래놀이를 진행 하였으며 매회기마다 모래상자를 창조하였다. 아동은 17 회기의 모래놀이를 통하여 아동의 내면적 변화와 자아발달의 단계를 경험하였다. 아동은 모래놀이를 하는 과정에서 애착외상으로 인한 미분화된 자아의 혼란스러움으로부터 분화된 자기가 나타났고 또래 관계 안에서 자신의 의사를 분명히 표현할 수 있는 자아기능 의 발달과정을 보여주었다.

도라칼프(Doraa Kalff, 1980/2003, as cited in Turner, 2009)의 첫 번째 자아 발달의 단계는 동식물 단계이다. 내담자의 경우 5회기까지의 모습이 이 단계에 해당된다. 아동은 모래놀이 초기 1 회기 5 회기에서는 자신의 혼돈되고 혼란스러운 내적 불안과 갈등을 손으로 모래를 섞으며 분출하고 해소하며, 자신의 무의식에서의 혼돈과 무질서를 치유해가는 과정을 보여 주었다. 즉, 모래놀이 초기의 혼돈단계로서 아동의 분화되지 않는 혼란스러운 자아의 측면 을 물과 모래를 섞으며 반복하는 과정에서 자신의 감정을 분출하였다.

두 번째 단계는 전투의 특징을 띤다. 모래놀이 중기인 6회기 14회기 에 아동은 퇴행을 통해 심리적인 재탄생을 경험하였으며, 자신의 갈등을 해소하고 아직 부족한 부분이 있지 만 모래상자 중앙에 중심화가 이루어지는 모습을 보여 주었다. 이과정은 아동의 모로부터 억압된 손상된 자아의 회복의 여정으로 보인다. 또한 모로부터 정서적 돌봄을 경험하지 못 하고 억압된 감정에 대한 갈등을 치유하고 긍정적으로 성장하고자 하는 욕구를 계속해서 표출하였다. 이 과정에서 아동은 자신의 무의식적 내면의 갈등을 회복 하려는 내적인 에너 지와 투쟁하는 모습을 보여주었는데 아동은 새로운 것과 낡은 것의 싸움을 통하여 새로운 성장을 향해 나아가며, 그 결과 새로운 관계가 형성되는 회복의 과정을 경험하게 되었다. 이 과정에서 모의 보고에 따르면 친구에게 "나대지마, 내가 왜 그래야 하는데, 내방을 갖고 
싶어” 등 또래 관계 안에서 자신의 의사를 언어로 분명히 표현 하였으며 또한 모에게도 자 신의 욕구를 언어로 표현 하는 모습을 보여 주었다.

세 번째 단계는 일상으로의 적응 이다. 15 회기 17 회기가 이에 해당된다. 15 회기에서 "모 래상자의 이 아이들은 공원에서 만나서 집까지 같이 왔어요. 이 아이들은 서로 맞는 친구 들이예요" 친구를 초대해서 생일 파티를 하는 장면이다. 아동은 실제로도 또래와 관계하고 자신의 의사를 표현하는 모습을 보였다. 마지막 모래상자인 17 회기에서는 모래상자 작업을 통해 새로운 의식성의 탄생을 상징하는 피규어와 숫자 4,16 을 등장시킴으로써 출발과 시 작의 힘을 엿볼 수 있었다. 아동은 모래상자를 작업하면서 자신의 갈등과 문제를 해결하는 방향으로 에너지가 흐르고 있음을 시사했다. 또한 아동이 양육의 상징인 음식 피규어 들을 사용함으로써 Self에너지의 돌보고 양육하는 측면을 보여주었다.

아동은 모래놀이치료 후반부에 상징적으로 완전함과 전체 감의 표현인 원, 네모 등의 만 다라 이미지를 나타내며, 모래작업을 통한 본능적인 힘의 통합을 의미 있게 보여주었다. 아 동은 자신의 혼돈의 상태와 정서적 결핍을 통합으로 성장해 나가는 모습을 보여주었다. 상 담 말기 아동은 자아의 발달과 더불어 자아의 관계를 개선하는 과정에서 사회성의 발달을 통해 친밀한 관계를 맺을 수 있는 능력을 향상시켰다. 아동이 친구에게 자신의 의사를 언 어로 표현하는 모습은 아동이 모래놀이를 통하여 모와의 손상된 애착의 문제와 정서적 조 절의 어려움을 극복하였고, 아동 스스로 자신의 문제행동을 개선하려는 의지를 가지게 되 었다. 모래놀이 후반에 아동은 스스로 학교를 갈 수 있게 되었으며 집에서는 혼자 있고 싶다며 자신의 방을 줄 것을 요구 하였다. 또래와의 관계에서도 변화가 있었는데 친구 집 에서 자고 오겠다고 하기도 하며 모와의 분리를 통해 또래관계 속으로 들어가는 모습을 보 였다. 아동은 견뎌주고 담아주는 치료사와의 관계경험을 통해 안정된 정서를 유지해 나가 면서 사회적 환경 안에서의 갈등을 해결하고 적응해 나갈 수 있게 되었다. 그 결과 아동은 자신과 타인을 수용하는 능력과 정서조절 능력이 발달되고 학교적응력이 향상되는 긍정적 인 변화를 보여주었다.

이 사례는 모의 과잉보호와 관계외상의 원인이 되는 부정적인 양육으로 인해 아동이 독 립과 자율성의 발달을 이루지 못하고 손상된 자아로 인해 겪게 되는 행동적, 정서적 어려 움을 모래놀이를 통해 자신의 내면으로의 하강을 시작해 건강한 자아와 자기를 발달시켜 어머니로부터 분리되기까지의 치료과정에 대한 이해를 높여 주었다. 따라서 아동이 놀이를 통해 표현하는 이야기를 잘 듣고 이해할 수 있는 치유여정을 함께 하는 조력자로서 따뜻하 고 공감적인 치료사 역할의 중요성을 다시 한 번 확인할 수 있었다는 데에 의의가 있다. 
Journal of Symbols \& Sandplay Therapy, Vol.11 No.2.

\section{참고문헌}

강나정 (2008). 아동이 지각한 부부갈등과 사회적지지가 자아존중감에 미치는 영향. 이화여 자대학교 교육대학원 석사학위논문.

박은희 (2012). 구조화된 집단 모래놀이치료가 아동의 자아 존중감과 정서 지능에 미치는 효과. 명지대학교대학원 석사학위논문.

박행자 (2011). 분석심리학적 관점에서 본 물의 상징에 대한 연구. 모래놀이치료연구, 7(2), 59-72.

박행자 (2012). 아동의 모래놀이치료과정에서 나타나는 카오스, 죽음, 재탄생. 명지대학교대 학원 박사학위논문.

배자영 (2012). 부모-자녀 애착정도가 친구관계에 미치는 영향에서 아동 성격특성의 매개효

과. 단국대학교 교육대학원 석사학위논문

이 슬 (2015.) 모래상자놀이가 불안정 애착 모-자의의사소통에 미치는 효과. 대구대학교 재 활과학대학원 석사학위논문

이영주 (2019). 관계외상을 경험한 아동의 모래놀이치료과정에서 나타난 모성 상징 및 모-자

녀 관계에 대한 질적 연구. 한양대학교대학원 박사학위논문.

이유경 (2004). 원형과 신화. 서울: 이끌리오

이의철 (2011). 모래놀이가 아동의 자아발달단계, 자아존중감과 사회성에 미치는 영향에 관

한연구: 성차를 중심으로. 가천의과대학교 대학원 석사 학위논문.

장난이 (2010). 모래놀이치료가 $\mathrm{ADHD}$ 성인의 우울과 자아존중감 및 대인관계에 미치는 효

과. 남서울대학교 대학원 석사학위논문.

장미경 (2017). 분석심리학적 모래놀이치료. 서울: 학지사

최경숙 (2006). 아동발달 심리학. 서울: 교문사.

Abt, T. (2005/2007). 융 심리학적 그림해석. 이유경 역. 서울: 분석심리학연구소

Ackroyd, E. (1993). 꿈 상징 사전. 김병준 역. 서울: 한국심리치료연구소

Ammann. R. (2001). 융 심리학적 모래놀이치료. 이유경 역. 서울: 분석심리학연구소.

Bowyer, R. (1970). The Lowenfeld world technique: Studies in personality. London: Pergamon Press.

Cooper, J. C. (1978). An illustrated encyclopedia of traditional symbols. New York: Thames \& Hudson.

(Trans. Korean into 1994)

David, F. (1993). 상징의 비밀. 최승자 역. 서울: 문학동네.

Eastwood, P. S. (2006). 모래놀이치료와 數상징. 정정순 외 역. 서울: 학지사.

Elkid, D., \& Weiner, I. B. (1978). Development of child. New York: Wiley \& .Sons.

Eliade, M. (1990). Image and symbol: Studies in religious symbolism. (P. Mariet, Trans.). Princeton, NJ: 
Princeton University Press. (Original work published 1952).

Grubbs, G. (1995). A comparative analysis of the sandplay process ofsexually abused and nonclinical children. The Arts in Psychotherapy, 22(5), 429-446.

Jung, C. G. (2006). 인간과 문화. 한국 융 연구원. C. G. Jung 저작 번역서 9권. (한국 융 연구 원 C. G. 융 저작 번역위원회 역). 서울: 솔 출판사.

Kalff, D. M. (1980). Sandplay: a psychotherapeutic approach to the psyche. SantaMonica, California: Sigo Press.

Neumann, E. (2004). Ursprungsgeschichte des Bewusstseins. Dusseldorf: Walter. (Trans, into Korean in 2007)

Neumann, E. (2004/2010). 이유경 옮김. 의식의 기원사. 서울: 분석심리학연구소.

Turner, B. A. (2005). The handbook of sandplay therapy. Los Angeles, CA: Temenos Press.

Robert, A. J. (2006). 신화로 읽는 여성성 "She". 고혜경 역. 서울: 동연. 